NBER WORKING PAPER SERIES

\title{
CHILD POVERTY, THE GREAT RECESSION, AND THE SOCIAL SAFETY NET IN THE UNITED STATES
}

\author{
Marianne Bitler \\ Hilary Hoynes \\ Elira Kuka \\ Working Paper 22682 \\ http://www.nber.org/papers/w22682 \\ NATIONAL BUREAU OF ECONOMIC RESEARCH \\ 1050 Massachusetts Avenue \\ Cambridge, MA 02138 \\ September 2016
}

We thank Patty Anderson, Chloe East, Kosali Simon, and George Saioc for generously sharing their expertise and data on state safety net policies and state policies regarding foreclosures, and Chris Wimer for sharing historical supplemental poverty thresholds from Fox et al. (2015a). Dorian Carloni and Krista Ruffini provided excellent research assistance. This research was partially funded by a grant from UNICEF. The views expressed herein are those of the authors and do not necessarily reflect the views of the National Bureau of Economic Research.

At least one co-author has disclosed a financial relationship of potential relevance for this research. Further information is available online at http://www.nber.org/papers/w22682.ack

NBER working papers are circulated for discussion and comment purposes. They have not been peer-reviewed or been subject to the review by the NBER Board of Directors that accompanies official NBER publications.

(C) 2016 by Marianne Bitler, Hilary Hoynes, and Elira Kuka. All rights reserved. Short sections of text, not to exceed two paragraphs, may be quoted without explicit permission provided that full credit, including $(\odot$ notice, is given to the source. 
Child Poverty, the Great Recession, and the Social Safety Net in the United States

Marianne Bitler, Hilary Hoynes, and Elira Kuka

NBER Working Paper No. 22682

September 2016

JEL No. I3,J22

\begin{abstract}
$\underline{\text { ABSTRACT }}$
In this paper, we comprehensively examine the effects of the Great Recession on child poverty, with particular attention to the role of the social safety net in mitigating the adverse effects of shocks to earnings and income. Using a state panel data model and data for 2000 to 2014, we estimate the relationship between the business cycle and child poverty, and we examine how and to what extent the safety net is providing protection to at-risk children. We find compelling evidence that the safety net provides protection; that is, the cyclicality of after-tax-and-transfer child poverty is significantly attenuated relative to the cyclicality of private income poverty. We also find that the protective effect of the safety net is not similar across demographic groups, and that children from more disadvantaged backgrounds, such as those living with non-Hispanic black or Hispanic, single, or particularly immigrant household heads-or immigrant spouses, experience larger poverty cyclicality than non-Hispanic white, married, or native household heads with native spouses. Our findings hold across a host of choices for how to define poverty. These include measures based on absolute thresholds or more relative thresholds. They also hold for measures of resources that include not only cash and near cash transfers net of taxes but also several measures of medical benefits.
\end{abstract}

Marianne Bitler

Department of Economics

University of California, Davis

One Shields Avenie

Davis, CA 95616

and NBER

bitler@ucdavis.edu

Hilary Hoynes

Richard \& Rhoda Goldman School of Public Policy

University of California, Berkeley

2607 Hearst Avenue

Berkeley, CA 94720-7320

and NBER

hoynes@berkeley.edu
Elira Kuka

SMU, Department of Economics

3300 Dyer Street Suite 301

Umphrey Lee Center

Dallas, TX 75275-0496

United States

ekuka@smu.edu 


\section{INTRODUCTION}

The Great Recession led to massive job loss and historic increases in unemployment durations. Employment in the United States fell by more than 8 million between January 2008 and December 2009 and unemployment rose to a peak of 15.6 million persons in October 2009 (both seasonally adjusted). In the meanwhile, median real household cash income also fell, from $\$ 57,357$ in 2007 to $\$ 52,690$ in 2011 , and has turned back upward to $\$ 53,657$ in 2014 (U.S. Census 2015, figures are in real 2014 dollars).

These trends in median cash income are useful but are unlikely to tell the whole story. There is substantial evidence that the effects of economic cycles are larger for less-skilled workers (Hoynes, Miller and Schaller, 2012; Gundersen and Ziliak, 2004), thus the effect of the Great Recession on household incomes may be larger in relative terms for households in the lower end of the income distribution. ${ }^{1}$ Additionally, the overall trend in household income captures not only the shock to employment and earnings, but the response of the social safety net including public assistance (e.g., Food Stamps), social insurance (e.g., Unemployment Insurance) programs and the stimulus programs of 2008 and 2009. To what extent did these policies and programs mitigate the earnings and income losses of the Great Recession?

In this paper, we empirically investigate these issues. First, we estimate the cyclicality of being below various multiples of the ratio of household income relative to poverty and how these vary as we move up the income to needs distribution. Second, we examine how the broader social safety net mitigates the income loss in economic downturns, capturing effects on a broad post tax and transfer measure of household resources. We do this in an aggregate fashion, capturing the overall net effect of the safety net as well as the labor market shock on cyclicality for these measures. Third, we explore how these findings differ for married compared to single heads, by race and ethnicity, and

\footnotetext{
${ }^{1}$ Of course the link between the business cycle and income/income to needs need not be monotonic in income. Parker and Vissing-Jorgensen $(2009,2010)$ show that the upper end of the income distribution is quite responsive to business cycles.
} 
for immigrant versus native households. Throughout our analysis, we focus on children and examine household income relative to poverty. Children are a particularly important group because they consistently have the highest poverty rates in the U.S. ${ }^{2}$ A further reason to focus on children is that poverty has deleterious effects on children (e.g., Brooks-Gunn and Duncan, 1997) and they are the beneficiaries of much of the safety net.

In this analysis, we use data on child poverty by state and year for the period 2000 to 2014 and study the effect of the business cycle on children's economic wellbeing. By using data for 2000 to the present, we focus on the social safety net as currently structured, in the post-welfare reform world. We estimate state panel data models and measure the economic cycle with the state unemployment rate. We identify the key parameter - how changes in the business cycle affect child poverty - using variation in the timing and severity of cycles across states, controlling for state and year fixed effects. In our models, we do not seek to analyze the causal effects of specific elements of the social safety net nor household behavioral responses to specific programs, although our reduced form analysis does also incorporate the net behavioral responses to the current safety net programs and any changes to these programs in our time period. Instead we are interested in evaluating the overall effects of the social safety net writ broadly and how it varies as we move up the income distribution.

Given our interest in understanding the role that the social safety net plays in mitigating the adverse effects of shocks to earnings and income, in our main results we use two measures of resources to construct child poverty. The first, private income poverty, uses a resource measure for households that includes earned income, private transfers, and asset income. The second, after-taxand-transfer poverty, uses a resource measure equal to private income plus cash and near-cash inkind government transfers (including social insurance) less net taxes. As we discuss below, our measure of after-tax-and-transfer poverty shares many (though not all) features of the Supplemental

\footnotetext{
${ }^{2}$ Our own previous work (Bitler and Hoynes, 2015) has shown that the net of tax and transfer system resources of the elderly, by contrast to children and prime age adults, are not very responsive to cyclical conditions.
} 
Poverty Measure (SPM), the new poverty statistic released by the Census beginning in 2011. (Note we discuss alternative ways to measure poverty and the implications of their use below.)

For these two resource measures, we construct, for each state and year, the share of children with income below 50 percent, 100 percent, 150 percent and 200 percent of the household's poverty threshold. For the poverty threshold, we use the Historical SPM thresholds developed by Fox et al. (2015a), who employ available historical data to construct poverty thresholds back to 1967 consistent with the Census Bureau's current SPM threshold. In sum, our measure of after-tax-and-transfer poverty differs from the Census official poverty by 1) using a post-tax-and-transfer measure of income including near-cash in-kind transfers, 2) using the Historical SPM thresholds from Fox et al. (2015a) and 3) treating the household as the relevant unit for measuring poverty. These choices address many of the critiques of the official poverty measure made by Citro and Michael (1995) and Blank (2008). ${ }^{3}$

Using these data on income relative to poverty, we establish our main results comparing the cyclicality of private income poverty and the gradient as we move up the income to poverty distribution. Second, by comparing the cyclicality of private income poverty to that of our after-taxand-transfer poverty, we reveal the aggregate protection that is provided by the safety net. In particular, our results speak to the mitigating role of public assistance programs and tax credits (including Food Stamps or SNAP, Temporary Assistance to Needy Families (TANF), Supplemental Security Income (SSI), School Lunch, the Low-Income Home Energy Assistance Program (LIHEAP), public housing, the Earned Income Tax Credit (EITC), and the Child Tax Credits) and social insurance programs (Unemployment Insurance (UI), Social Security Old Age and Disability Income).

Ex ante, we would expect the safety net to partially offset the losses to private income in

\footnotetext{
${ }^{3}$ As we discuss more below, by using the Historical SPM thresholds, we have a quasi-relative poverty measure rather than an absolute one, comparing resources to a threshold set by families at the top of the bottom third of the income distribution. Thus, as consumption at that point in the distribution changes across time, so too would our sense of whether a household was in poverty even if income remained fixed.
} 
downturns. Aggregate program statistics show that the social safety net provided significant support to households affected by the Great Recession. In 2011, Food Stamp expenditures amounted to $\$ 72.8$ billion and more than one in seven people in the U.S. received benefits from the SNAP program. The maximum duration of Unemployment Insurance benefits was extended to up to 99 weeks during the Great Recession, far beyond the normal maximum of 26 weeks or even the Extended Benefit maximum of 52 weeks in most states. Further, at the center of the 2009 stimulus, there were temporary increases in the maximum benefits paid out for Food Stamps, the EITC, and UI as well as in temporary tax relief (the Making Work Pay tax credit). The total cost of these expansions was over $\$ 200$ billion. $^{4}$

In addition to these important changes during the Great Recession, the social safety net for lower-income families has undergone a transformation since the last severe recessions, which took place during the early 1980s. Welfare reform in the mid-1990s led to a massive reduction in the share of families (Blank, 2002), and more specifically poor families (Floyd, Pavetti, and Schott, 2015), receiving cash welfare. At the same time, the EITC expanded substantially in generosity (Hotz and Scholz, 2003). The end result is that the U.S. safety net for low-income families with children has changed from one based on out-of-work assistance to one based on in-work assistance (Bitler and Hoynes, 2010, 2016; Moffitt, 2015). This may have important implications for the protective effects of the safety net for low-income households.

Our analysis yields several important findings. Using our after-tax-and-transfer poverty measure, we find that child poverty rises in recessions and falls in expansions, and the level of cyclicality is higher at lower levels of the income distribution. Importantly, we find striking evidence that the safety net provides protection; that is, the cyclicality of after-tax-and-transfer poverty is significantly attenuated relative to the cyclicality of private income poverty, controlling for fixed

\footnotetext{
${ }^{4}$ The breakdown of the total costs is as follows: Food Stamps (\$48 B), EITC (\$5.1 B), UI (\$61.0 B) and Making Work Pay (\$104.4 B). The American Recovery and Reinvestment Act (ARRA) also included expansions to TANF. While Food Stamps and the EITC are targeted at low income families, the stimulus benefits of extended UI and Making Work Pay will also accrue to higher income families.
} 
state characteristics and national shocks. The net result is that after-tax-and-transfer child poverty rose modestly in the Great Recession, while child private income poverty increased substantially. These effects are not equal across groups, as we find that a given change in the unemployment rate leads to a higher probability that children fall into poverty in households headed by single parents, Hispanics, and most significantly, for children in households with immigrant-heads or spouses.

Our findings are robust to how we measure child poverty, including whether instead of our Historical SPM threshold we use the official poverty threshold (which is absolute), an "anchored" supplemental poverty threshold (Wimer et al., 2013, also absolute), or even the OECD's relative poverty measure (income less than 60 percent of the median yearly household income) ${ }^{5}$ In our main estimates, we exclude any value of public (and employer-provided) health insurance coverage from our measure of resources. Our results are robust to adding the Census Bureau's fungible value of public health insurance (and a value for employer-provided insurance) or using the SPM approach of deducting from resources out of pocket medical expenses (as well as work expenses including child care). The results are also robust to adding state-level time-varying policies, individual demographic controls, and state linear trends; as well as to not weighting by population, to using alternate lag structures for the effects of labor market shocks, and to an alternative definition of the sharing unit.

Our work adds to a large and rich literature on the measurement and determinants of poverty spanning many decades (e.g., Blank and Blinder, 1986; Blank, 1989; Cutler and Katz, 1991; Blank and Card, 1993; Blank, 1993; Freeman, 2001; Gundersen and Ziliak, 2004; Hoynes, Page, and Stevens, 2006; Moffitt, 2012; Moffitt, 2015; Hardy, Smeeding, and Ziliak, 2015; Organisation for Economic Cooperation and Development, 2015). We contribute to this literature. First, we focus on child poverty and focus on the recent Great Recession period. Second, we analyze how the cyclicality varies as we move up the income to poverty distribution and quantify the role of the social safety net in mitigating losses. Third, we are the first to show the remarkable stability of the cyclicality across

\footnotetext{
${ }^{5}$ See Burkhauser (2009) for a discussion of the key distinctions between relative and absolute measures.
} 
quasi-relative measures (our main results, using Historical SPM thresholds), absolute measures

(official poverty thresholds and the anchored SPM thresholds) and relative measures (OECD

thresholds), and all using an after-tax-and-transfer measure of resources. Additionally, as suggested

by Blank (2008) and Citro and Michael (1995) as well as many others (Fox et al., 2015a, 2015b), we

come closer to capturing disposable income shared by children and adults by using a broader unit

rather than the narrow Census family unit and by counting post-tax and transfer income. ${ }^{6,7}$ We also

complement recent work by Larrimore, Burkhauser, and Armour (2015) who focus on the stabilizing

role of the safety net and the cycle in various recessions. ${ }^{8}$

Our next section describes our data and how we measure poverty. Section 3 provides a

summary of the Great Recession and presents the basic time series evidence on child poverty.

Section 4 describes the major social safety net programs and how they changed during the Great

Recession. Section 5 examines the cyclicality of poverty, Section 6 examines the robustness of our

main findings, and Section 7 concludes.

\section{MEASURING CHILD POVERTY}

Official poverty in the U.S. is measured using an absolute standard, in contrast to the relative poverty measure used in many other countries and the OECD (Organisation for Economic

Cooperation and Development, 2015, Burkhauser 2009). The U.S. official poverty measure is determined by comparing total pre-tax family cash income to poverty thresholds, which vary by family size, the number of children, and the presence of elderly persons. If the family has pre-tax

\footnotetext{
${ }^{6}$ A number of recent studies have looked at the Supplemental Poverty Measure (Short, 2011, 2013) to evaluate poverty and deep poverty over time (Fox et al. 2015a, 2015b; Wimer at al. 2013). As with Fox et al. (2015a, 2015b), we find that deep ATT poverty is less cyclical than are measures of 100 percent, 150 percent or 200 percent of poverty. Like Fox et al. (2015a), we find that excluding the safety net from resources leads to poverty being more cyclical.

${ }^{7}$ There are other approaches to poverty measurement that are beyond the scope of our paper. The development literature as well as Meyer and Sullivan $(2011,2012)$ argue that consumption or expenditures are superior to income for measuring well-being. However, Bavier $(2008,2014)$ documents that a more comprehensive resource measure goes a long way towards reconciling differences between income and consumption measures of poverty. ${ }^{8}$ Larrimore, Burkhauser, and Armour (2015) look at detailed trends in market income and after-tax and transfer income across multiple business cycles, with attention to the top and bottom quintiles. They also use an equivalence scale adjusted income measure, and point out the relative importance of declines in wage earnings in the severe 1980s recessions relative to employment loss in the Great Recession.
} 
cash income below the relevant threshold, then they are deemed to be poor. The family unit used for official poverty consists of all related individuals in the household ${ }^{9}$ and all persons in the family have the same poverty status. In 2014, for example, the poverty threshold for a family of four (two adults plus two children) was $\$ 24,008$ and 21.1 percent of children were poor.

The official poverty measure has numerous drawbacks (Citro and Michael, 1995, Blank, 2008). Of particular relevance for our work, the measure of family cash income is not a complete measure of family resources. It excludes non-cash government transfers (in-kind transfers such as food stamps and housing subsidies) as well as taxes and tax credits (notably the EITC and Child Tax Credits as well as other income and payroll taxes). Additionally, there is no geographic variation in the official poverty thresholds, despite wide variation in costs and wages across regions. ${ }^{10}$ These limitations in the official poverty definition have been noted for decades, and in 2011, the Census released a new poverty measure - the SPM - designed to improve on the official poverty measure (Short, 2011). The SPM resource measure expands to include the cash value of various in-kind transfers and nets out taxes (and deducts from income child support payments, medical out of pocket expenditures, and work expenses including child care). Additionally, the SPM family unit is modified to include cohabitors and their children. The Census SPM thresholds are defined to be the average between the 30th and 36th percentiles of the distribution of consumer expenditures on food, clothing, shelter, and utilities plus an additional 20 percent to account for additional necessary expenditures. This makes the SPM a "quasi-relative" poverty measure in that the threshold increases with consumption levels of families at the top of the bottom third of the consumption distribution. Additionally, the thresholds are adjusted to reflect geographic variation in costs and spending, owner versus rental status, and family size (Short, 2013).

\footnotetext{
${ }^{9}$ Note that this Census measure of family is those who are married or related by blood or adoption and thus excludes cohabitants or others who may share resources.

${ }^{10}$ Furthermore, the thresholds fail to adjust for many categories of expenses (e.g., shelter, clothing, work-related expenses, medical expenses, and utilities), and thus do not necessarily capture the relevant measures of needs. The thresholds are also updated annually by the CPI-U, which may not well capture changes in needs across all locations.
} 
In our analysis, we develop a poverty measure is highly aligned with — though not identical to - the Census SPM. We use data from the Annual Social and Economic Supplement (ASEC) to the Current Population Survey (CPS), administered to most households in March every year. The ASEC is an annual survey that collects labor market, income, and program participation information for individuals for the previous calendar year, as well as demographic information from the time of the survey. Our sample uses the 2001 through 2015 CPS surveys, corresponding to the 2000 to 2014 calendar years. The CPS is used to report official poverty and, since 2011, the SPM each year.

We use the CPS to construct private income (PI) poverty and after-tax-and-transfer (ATT) poverty. Appendix Table 1 provides details on the sources of income in our two measures of resources and compares them to the income sources included in both official poverty and the Census SPM. Private income includes earned income, asset income, and private transfers (child support, alimony, private disability and retirement). Our after-tax-and-transfer resource measure, developed in Bitler and Hoynes (2010, 2016), includes private income plus cash transfers (AFDC/TANF, Social Security, SSI, UI, veterans payments and workers' compensation), the cash value (as reported by the household or imputed by the Census Bureau) of non-cash in-kind programs (food stamps, school lunch, housing subsidies, and energy subsidies), tax credits (the EITC, child tax credits, and stimulus payments) and then subtracts payroll, federal, and state income taxes. We use the NBER TAXSIM model for all tax variables (though the results are virtually identical if we use the Census imputations of taxes provided in the CPS).

As is clear from Appendix Table 1, one way our ATT poverty measure differs from the Census SPM is that we do not incorporate medical out-of-pocket expenditures (MOOP) or workrelated expenses (including child care and other expenses), which are subtracted from resources by the Census SPM as are child support payments made. While there is significant agreement about the importance of adding the value of in-kind benefits to expand the resource measure, there are a variety of approaches that are used to take into account the value of public (and private) health insurance. 
The Congressional Budget Office, in its analyses of the concentration of and trends in income, uses the government's average cost of providing Medicaid and Medicare as well as employers' contributions to health insurance to value health insurance (Congressional Budget Office, 2014). Until the SPM, the Census Bureau has used the fungible value of public health insurance, essentially counting the average cost of Medicaid and Medicare only if household income is above the amount needed for basic food and housing needs. ${ }^{11}$ Finally, the Census SPM deducts out-of-pocket medical expenses from income (rather than the $\mathrm{CBO} /$ Census approach of adding the value of the insurance coverage provided). In our view, none of these approaches satisfy the ideal of including the "insurance value" of this benefit as well as what families spend in practice. As such, in our main estimates we make no adjustment for MOOP or the value of public health insurance (or private health insurance). It turns out, as we show below, whether and how we handle this has no impact on the main results in the paper; results that either exclude MOOP (and other fixed costs of work) from resources or add the fungible value of Medicare and Medicaid and employer provided insurance to resources are nearly identical to our main findings.

For each of our poverty measures, we calculate resources and poverty at the household level. ${ }^{12}$ This is another difference from the SPM-their sharing unit is composed of related individuals plus foster children and cohabitors and their children. However, the CPS only began identifying cohabitors for all of the adults in the household in 2007 , and thus this measure is not available for our full sample period. Our household sharing unit also differs from one used by the Census to calculate official poverty, which consists of only persons married or related through birth or adoption. One advantage of our household measure is the inclusion of cohabitants and others who share resources. Additionally, the CPS only measures use of food stamps at the household level, so a

\footnotetext{
${ }^{11}$ The fungible value represents the benefit of being covered by Medicare and Medicaid "to the extent that they free up resources that could have been spent on medical care." The estimated fungible value depends on family income, the cost of food and housing needs, and the market value of the medical benefits (Census Bureau, Current Population Reports, P60-186RD).

${ }^{12}$ We drop the small number of unrelated children, as does the Census Bureau when constructing official poverty.
} 
household sharing unit is appealing for this reason. ${ }^{13}$ Therefore, private and ATT incomes are summed across household members and total household income is compared to the appropriate poverty threshold using the appropriate household structure and size; an indicator for this value being below the threshold is then attached to all household members. Since here we study child poverty, we limit the sample to those aged below 18 at the survey month. When we analyze subgroups, we use the demographic characteristics of the head of household (or in the case of immigration status, the spouse of the head as well).

Finally, we use the Historical SPM thresholds developed by Fox et al. (2015a) for our poverty thresholds. The new Census SPM thresholds are only available beginning in 2009 so it is not adequate for our 2000 through 2014 analysis. Fox et al. (2015a) implement nearly all of the SPM methods and construct thresholds back to 1967 with available Consumer Expenditure Data. Due to data limitations, the Fox et al. (2015a) Historical SPM does not adjust the thresholds for geographic variation in costs and spending. Below, we explore the sensitivity of our main results to the poverty threshold, in particular also using the official US poverty threshold, the "anchored" SPM (Wimer et al., 2013), as well as an OECD relative poverty threshold. Wimer et al. (2013) take the 2012 SPM threshold and backcast it by adjusting for changes in prices using the CPI-U-RS. For our measure of ATT poverty using the anchored SPM threshold, we take the same approach, starting with 2014 thresholds by household size and number of children, then collapsing to state (so the geographic variation matches our CPS data), and finally adjusting for changes in prices back to $2000 .{ }^{14}$ The OECD threshold is defined as 60 percent of the median of household-equivalized income. We implement this using our sample and resource measure and construct thresholds using the OECD's

\footnotetext{
${ }^{13}$ Receipt of LIHEAP is also only reported at the household level as is use of school lunch.

${ }^{14}$ Note that our measures will capture geographic variation in 2 ways. First, to the extent that thresholds in the official SPM on average vary by state, it will be incorporated in our anchored SPM thresholds. Second, to the extent that across or within state expenditures in the thresholds vary across state or within state by household size/number of children, we will capture that.
} 
standard equivalence scale applied to the household structure and number of persons. ${ }^{15}$ This gives us one quasi-relative measure (ATT poverty with Historical SPM thresholds), two absolute measures (ATT poverty with official poverty thresholds or anchored SPM thresholds) and one relative measure (ATT poverty with OECD thresholds). As we show below, our main results are robust to using any of these four alternative thresholds to define poverty.

\section{CYCLES, THE GREAT RECESSION, AND POVERTY}

We begin with a historical view of child poverty and economic cycles, examining the changes in child poverty that have occurred in the U.S. between 2000 and 2014 . Figure 1 presents (on the right axis) our primary measure of the economic cycle - the unemployment rate - annually over this period. Using the NBER dating, the Great Recession officially began in December 2007 and the unemployment rate rose from 5 percent in December 2007 to a peak of 10.0 percent in October 2009 (seasonally adjusted). While the recession officially ended in July 2009, it took another 6 years for the unemployment rate to return to its pre-Great Recession level reaching 5.0 (seasonally adjusted) in October 2015 (not shown). Figure 1 also presents (on the left axis) our two measures of child poverty annually for the same period. The solid line plots annual child private income poverty and the dashed line plots child ATT poverty, both measured using the Historical SPM threshold. Notably, private income poverty varies significantly with the business cycle. Using this pre-tax-andtransfer measure of resources, during the Great Recession child private income poverty rose by 6.0 percentage points, from 19.7 in 2007 to 25.7 in 2010. Similarly, we see an increase in private income child poverty during the recession of the 2000s. Turning to the poverty measure calculated using the more comprehensive measure of resources, child ATT poverty rose (only) by 2.1 percentage points during the Great Recession (this change is from 2007 (11.3) to 2010 (13.4)). This is our first evidence of the extent to which the social safety net provided protection against shocks to household earnings and income in the Great Recession.

\footnotetext{
15 The OECD equivalized scale equals 1 for the head plus 0.5 for each additional adult [age 14+] plus 0.3 for each child [age $<14$ ].
} 
In our main results, shown below, we explore these issues further by estimating the relationship between the business cycle and child poverty. In that analysis, we take advantage of the dramatic variation in the timing and magnitude of business cycles across U.S. states, controlling for fixed differences across states and aggregate secular trends. Here, we begin that analysis by presenting some descriptive findings on child poverty across states in the Great Recession. Figure 2 presents percent changes in real private income, government transfers, and government taxes (net), by state, over the Great Recession. In particular, we compare the pre-recession peak (captured by averages over 2006 to 2008) to the trough (captured by averages over 2009 to 2011), following the Census practice of pooling multiple years to construct state averages. ${ }^{16}$ The figure shows that during the Great Recession private income dropped for most states, but that transfers and taxes offset this drop. These changes represent average effects across all children of all income levels in the state. Figure 3 builds on this and shows the change in the child poverty rate, by state, where the changes are again over 2006 to 2008 to 2009 to 2011. For comparison, we present both poverty measures, with the blue bars representing ATT poverty and the open circles (with a bar) representing private income poverty. During the Great Recession, almost all states experienced increases in private income child poverty, with North Dakota and its oil and gas boom representing a notable exception. The role of the safety net in providing protection against these private income losses is also evident in the figure. The net effect is a dramatic variation in the changes in child poverty across states in the wake of the Great Recession. Some states, such as many New England states (Connecticut, Massachusetts) and others (Pennsylvania, West Virginia, Texas), experienced reductions in ATT poverty. However, other states such as Nevada, DC, and Arizona experienced increases in ATT poverty on the order of 5 percentage points. The figure is a useful starting point, but the usual caveats apply given its "single difference" statistic. Importantly, these differences may, to some degree, be

\footnotetext{
16 The Census uses two-year averages for all person poverty levels. Because we are analyzing a smaller sample (children rather than all persons) we have adopted a three-year average. We pool the three years of data (in real 2012 dollars) and take the population-weighted average over that.
} 
capturing short-run or longer-run trends as well as the cycle. We address these limitations by

estimating a state panel model, described below.

\section{THE SOCIAL SAFETY NET AND THE POLICY LANDSCAPE}

In this section, we give a brief summary of the cash and non-cash social safety net for families with children and summarize the important policy changes leading up to and during the Great Recession. We consider a broad definition of the social safety net including traditional meanstested cash programs (TANF, SSI), near cash in-kind means tested transfers (SNAP (formerly known as food stamps), housing subsidies, LIHEAP, child nutrition programs), tax credits (the EITC, the Child Tax Credits), and, in some specifications, means-tested public health insurance (Medicaid, Children's Health Insurance Program). ${ }^{17}$ Additionally, we consider unemployment insurance given its prominent place as income replacement after job loss (even though, unlike all of the above, it is not a program targeted to lower-income groups). We also consider elements of the temporary stimulus programs (implemented in 2008 and 2009). We choose these tax and transfer programs to comprise our working definition of the social safety net because of our ability to measure them in our household data (the CPS) along with their importance for low-income households with children (Short 2015, Moffitt 2015). ${ }^{18}$

These programs are summarized in Table 1, which presents the total cost (in billions) of each program in 2010, the trough of the recession. In 2010, UI spending topped the list at $\$ 150$ billion, although as a social insurance program it serves workers throughout the income distribution. The combined amount spent on tax credits, the EITC and the refundable portion of the CTC, amounted to $\$ 87.3$ billion, followed by SNAP at $\$ 64.8$ billion. Housing assistance (Section 8 and public housing) was $\$ 27.3$ billion. Much smaller is cash welfare, $\$ 12.4$ billion for TANF and \$9.4 billion for SSI

\footnotetext{
${ }^{17}$ Specifications which account for Medicaid's value also include the fungible value of Medicare and the value of employer provided health insurance in resources.

${ }^{18}$ As discussed earlier, Appendix Table 1 provides a complete list of all tax and transfer programs that we include in our ATT income measure. Transfer programs that we include in ATT income but that we do not describe here include Social Security retirement and disability benefits, veterans payments and workers' compensation. Taxes that we do not discuss here include federal and state income taxes and payroll taxes.
} 
(limiting to costs for covering children), and the other child food and nutrition programs. ${ }^{19}$ Medicaid expenditures (limiting to costs for covering children) were $\$ 67.2$ billion.

Before proceeding, we lay out what we do and do not seek to causally identify in our analysis. First, we use variation in the timing and severity of economic cycles across states to estimate the effects of the unemployment rate on various multiples of the child poverty threshold. By exploring the probability that children are in households under 50 percent, 100 percent, 150 percent and 200 percent of poverty, we identify how the cyclicality of income to poverty varies along the income to poverty distribution. Second, we evaluate the role of the social safety net by comparing the cyclicality of private income poverty to that of after-tax-and-transfer income poverty. The aim of the paper is not to estimate the effects of the policies and programs per se but instead the effects of the cycle and how the programs mitigate the shocks associated with the cycle. Our reduced form analysis does incorporate behavioral responses to the labor market shock, such as changes in employment and earnings of a spouse and changes in living arrangements.

\section{A. The Social Safety Net}

Cash Welfare (AFDC/TANF): Since 1935, Aid to Families with Dependent Children (AFDC) provided cash welfare for single-parent families with children. The program is means-tested, requiring families to satisfy income and asset tests. The benefits were structured in a manner typical for income-support programs: If a family had no income, they received the maximum benefit (guarantee) and as earnings increased the benefit was reduced by the benefit reduction rate. The benefit reduction rate was high for AFDC, 67 percent or 100 percent, providing strong disincentives for work (Moffitt, 1983). Concerns about work disincentives and disincentives to form two-parent families led to federal welfare reform, with enactment of the Personal Responsibility and Work

\footnotetext{
${ }^{19}$ Other food and nutrition programs relevant for children include WIC, School Breakfast Program and Child and Adult Care Food Program. SNAP is by far the largest, accounting for more than 70 percent of USDA spending on food and nutrition programs (Hoynes and Schanzenbach 2015). SNAP combined with National School Lunch Program (the second largest food and nutrition program), account for more than 80 percent of total food and nutrition spending.
} 
Opportunity Reconciliation Act (PRWRORA) in 1996. TANF, the program that replaced AFDC, includes work requirements (with financial sanctions for non-compliance), a maximum of five years of lifetime use of federally funded welfare, and in many states, enhanced earnings disregards. Importantly, welfare reform removed the entitlement to AFDC and federal funding was replaced with a (nominally fixed) block grant and states were given more flexibility to spend this funding on things besides cash assistance. Under both AFDC and TANF, benefits are relatively low; for example, in 1996, on the eve of welfare reform, the median state's benefit level was about 36 percent of the poverty guideline (U.S. House of Representatives, 1996). Since welfare reform, caseloads have fallen to historic lows; for example, the number of families receiving cash welfare (TANF/AFDC) per 100 families with children in poverty fell from 68 in 1996 to 23 in 2014 (Floyd, Pavetti, and Schott, 2015).

Food Stamps (SNAP): Like AFDC/TANF, Food Stamps is a means-tested program and benefits are based on maximum benefit level that is reduced with additional earnings using a benefit reduction rate. The Supplemental Nutrition Assistance Program (SNAP), as the program was renamed in 2008, provides a voucher that can be spent on most food items in the grocery store ${ }^{20}$ In contrast to AFDC/TANF, SNAP is a federal program with little involvement and few rules set by the states until quite recently, with a national income eligibility threshold and benefits being adjusted for changes in prices each year. SNAP is close to a universal program with eligibility extending to almost all those with that meet the income and asset rules. The benefit reduction rate for SNAP is relatively low (30 percent), the gross income eligibility threshold is higher (at 130 percent of poverty) than other U.S. cash welfare programs, and the program serves the working and nonworking poor. Welfare reform left Food Stamp rules relatively unaffected. ${ }^{21}$ However, beginning

\footnotetext{
${ }^{20}$ Despite its voucher form, the behavioral response to food stamps has been found to be similar to the response to cash (Fraker et al., 1992; Hoynes and Schanzenbach, 2009; Ohls et al., 1992).

${ }^{21}$ Welfare reform limited benefits for legal immigrants, who were deemed ineligible (though this was reinstated in 2002) and for able-bodied adults without dependents 18-49 (who were limited to 3 months of benefits in a 3 year period); the latter restriction was waived at state application when economic times were sufficiently bad.
} 
with regulatory changes in 1999 and continuing with the 2002 Farm Bill, the USDA has allowed states to make changes in how they implement the program's rules to facilitate obtaining access to benefits. This has led to a relaxation of asset requirements and expanded gross income eligibility in what has been called broad-based categorical eligibility (U.S. Government Accountability Office, 2007). Overall, SNAP spending increased substantially in the Great Recession (Bitler and Hoynes, 2016) and provides an automatic stabilizer for families and the broader economy. In 2014, SNAP provided benefits to 47 million persons in 22.7 million households.

Supplemental Security Income (SSI): SSI is a means-tested program providing cash benefits for low-income aged and disabled individuals. A 1990 Supreme Court decision relaxed the medical eligibility criteria for children and the SSI-child caseload has steadily grown since that time. Benefits for child SSI recipients average \$561 per month in April 2016 and about 1.3 million children currently receive the benefits (Social Security Administration, 2016).

Earned Income Tax Credit (EITC): The EITC is a tax credit available to lower-income families with positive earned income. It is refundable, so when a family's income is too low to generate tax obligations, the EITC liabilities are negative and the family receives a refund check from the Internal Revenue Service. The EITC schedule has three segments: the phase-in, flat, and phase-out ranges. At low earnings (in the phase-in range), the EITC functions as an earnings subsidy with subsidy rates of $34 / 40 / 45$ percent for families with $1 / 2 / 3$ or more children. At higher levels of earnings, beyond a narrow flat region, the credit is phased out at around a 21 percent phase-out rate. Expansions of the EITC, facilitated through tax acts in 1986, 1990, and 1993, have featured prominently in the movement toward more "in-work" assistance in the U.S. safety net (and with welfare reform, a decline in out-of-work assistance). In 2015 for a single mother with two children, the maximum EITC credit was $\$ 5,548$ (annual payment) and the phase-out range extended to those with earned income of up to $\$ 44,454$. In 2013 about 22 million families with children received the EITC with an average payment of \$3064 (Internal Revenue Service, 2016). 
Child Tax Credit (CTC): The CTC was introduced in 1997. It is structurally similar to the EITC (with a phase-in, flat and phase-out range), but more universal in design and less targeted towards lower-income families. Since 2003, the maximum credit is $\$ 1,000$ per child (it is set nominally and unlike the EITC does not change with prices each year). The CTC's wide flat region (where the credit is maximized at $\$ 1,000$ ) and a low phase-out rate (5 percent) combine to generate high income eligibility limits: In 2015 , the CTC is available to families with incomes up to $\$ 150,000$ (if married with two children) or $\$ 115,000$ (if single with two children). The CTC is a nonrefundable credit, which limits the value of the credit for low-income families (who are less likely to have positive tax liabilities). However, a refundable CTC (called the Additional Child Tax Credit) was introduced in 2001 and expanded significantly in 2009 as part of the stimulus (and recently became permanent). Currently, the Additional CTC provides a refundable credit equal to 15 percent of earnings above $\$ 3,000$. This has significantly enhanced the benefits of the CTC for lower-income families (Hoynes and Rothstein, 2016).

Unemployment Insurance (UI): Unemployment insurance provides temporary and partial earnings replacement for involuntarily unemployed individuals with recent employment. As a social insurance program, UI is not means tested (limited to those with low incomes) and eligibility is a function of earnings history. UI benefits consist of three separate programs. Recipients receive benefits for a fixed duration, typically up to 26 weeks, through regular state benefits, funded by employer contributions. Under the Extended Benefits program, jointly funded by states and the Federal government, UI benefits can be extended for 13 or 20 additional weeks in states experiencing high unemployment rates. Lastly, in most major downturns, Congress has enacted emergency extensions to unemployment; these programs tend to be relatively short lived and are explicitly counter-cyclical and fully federally funded.

The CPS data also allow for measurement of housing subsidies and the National School Lunch Program, both means-tested transfer programs for income-eligible families, as well as 
subsidies for spending on energy (LIHEAP). In some specifications, we include the Census measure of the "fungible value" of public health insurance for children and parents, Medicaid and the Children's Health Insurance Plan (CHIP). ${ }^{22}$ Originally, Medicaid was limited to families (and individuals) who received cash welfare (now TANF or SSI). However, with policy expansions in the mid-1980s through the 1990s, Medicaid (and subsequently, post-1997, CHIP) expanded to children (and pregnant women) beyond those participating in cash welfare (Gruber, 1997). The number of children enrolled in Medicaid now totals 32.7 million (in fiscal year 2011) almost a tripling from the 11.2 million in 1990 (Centers for Medicare and Medicaid Services, 2013).

This discussion makes clear that heading into the Great Recession, the social safety net has moved away from cash welfare and towards tax credits and in-kind transfers. This represents a major change in support for low income Americans.

\section{B. The Stimulus and Changes to the Social Safety Net in the Great Recession}

The American Recovery and Reinvestment Act of 2009 (ARRA) was passed in February 2009 and contained many elements that expanded the social safety net. The Food Stamp maximum monthly benefit was increased by 13.6 percent (this provision expired in October 2013) and the three-month time limit on Food Stamp receipt for able-bodied childless adults (ABAWDs) was suspended temporarily (states can also seek waivers if the local unemployment rate exceeds a threshold or if there are insufficient jobs). The 2009 ARRA also included a $\$ 5$ billion TANF emergency fund (temporarily expanding the block grant), expanded the EITC to include a more generous schedule for families with three or more children, expanded the refundable portion of the CTC, and reduced taxes through the introduction of the Making Work Pay Tax Credit (providing up

\footnotetext{
${ }^{22}$ While Medicare spending for children is small in magnitude, when we include the fungible value of Medicaid, we are also including the fungible value of Medicare as well as the employer contribution to health insurance premiums. In 2010, CMS reported that total Medicare spending on children 0-18 was $\$ 91$ million out of a total $\$ 489$ billion. By contrast total spending on children in Medicaid in 2010 was $\$ 96$ billion out of a total of \$366 billion (CMS, 2010).
} 
to $\$ 400$ per worker). ${ }^{23}$ There was also a 2008 Economic Stimulus that included a "recovery rebate" with maximum payments of $\$ 600$ ( $\$ 1,200$ for joint filers).

In the Great Recession, both extended and emergency programs provided extensions to the duration of UI (Rothstein, 2011). In June 2008, Congress enacted the Emergency Unemployment Compensation (EUC) program, which (eventually) raised maximum UI benefit durations to as long as 99 weeks given sufficiently high unemployment rates in the states. With passage of the 2009 ARRA, the full cost of extended benefits was shifted to the federal government; the ARRA also raised the weekly UI benefit by $\$ 25 .{ }^{24}$ These UI extensions expire when the unemployment rate within states declines below certain predetermined thresholds. Some states have responded to the slow recovery by cutting the maximum duration of their state benefits (e.g., North Carolina now has a maximum state duration of 19 weeks), while sequestration also led to some reductions in EUC benefits.

\section{Implications for Low-Income Households}

To gain some insight into the quantitative importance of these elements of the safety net for households with children, Figure 4 presents a summary of income components by source for our sample of children from the CPS. In particular, we calculate the share of total ATT income by source for children living in deep poverty (resources less than 50 percent of poverty, panel A), below 100 percent of poverty (panel B), below 150 percent of poverty (panel C), and below 200 percent of poverty (panel D). In each panel, we plot the percentage of total ATT income from the following sources: earned income, TANF, ${ }^{25}$ SSI, EITC and both CTCs, Food Stamps, other in-kind benefits

\footnotetext{
${ }^{23}$ The ARRA also included a one-time payment of $\$ 250$ per person for Social Security, SSI, and Veterans Disability Benefits.

${ }^{24}$ As is noted above, Extended Benefit UI program costs are shared by the states and federal government. Initially some states chose not to participate but eventually did so after the ARRA shifted the costs to the federal government.

${ }^{25}$ Note that this variable in the CPS also includes other state and local general assistance.
} 
(school lunch, housing subsidy, LIHEAP), UI, and other. ${ }^{26}$ We plot this for 2010, the trough of the Great Recession in terms of the U.S. annual unemployment rate. Several facts emerge from these graphs. First, TANF is providing minimal income; even for those in deep poverty, cash assistance (TANF plus general assistance) is only 4.2 percent of total income. SNAP, on the other hand, makes a significant contribution to incomes for those under 50 percent, 100 percent and 150 percent of poverty, ranging from 23.3 percent of income for those under 50 percent of poverty, to 19.6 percent for those under 100 percent of poverty, to 13.0 percent for those under 150 percent of poverty. The share of income from SSI ranged from 2.7 percent for those under 50 percent of poverty to 4.6 percent for those under 100 percent of poverty. Second, the tax-based safety net is important: the importance of the EITC (and both CTCs) is particularly evident at 100 percent poverty and beyond, supplying 9.3 percent of ATT income for those under 100 percent of poverty, 13.2 percent of ATT income for those under 150 percent of poverty, and 12.6 percent of ATT income for those under 200 percent of poverty. UI, on the other hand, is small in magnitude at all of these income to poverty levels and is never more than 4.5 percent of income at 100 percent poverty and above, and is only 2.8 percent of income for those in deep poverty. ${ }^{27}$

These findings are consistent with those in the Census report on the Supplemental Poverty Measure (Short, 2015). The report shows that the combined tax credits (EITC and CTC) are the biggest anti-poverty program for children, keeping 5 million children out of poverty. The second biggest anti-poverty program for children is SNAP, which keeps 2.2 million children out of poverty. These reductions are followed in magnitude by a decrease in children in poverty of 1.5 million for Social Security (retirement and disability), 1.0 million for public housing, 0.7 million for School

\footnotetext{
${ }^{26}$ The percentages sum to one hundred. "Other" sources include Social Security (Old Age and Disability benefits), veterans payments, workers' compensation, unearned private income (asset income, child support, alimony, private retirement and private disability) and federal and state taxes other than the EITC and CTCs.

${ }^{27}$ Meyer, Mok and Sullivan (2009) document that there is extensive underreporting of these programs. Sherman and Trisi (2015) adjusts for underreporting using the Urban Institute's TRIM microsimulation model and finds that government benefits play a large role in reducing poverty, and while the numbers are different from Short (2015), they still find that post welfare reform, SNAP plays a large role in lifting children out of deep poverty.
} 
Lunch, 0.7 million for SSI, 0.6 million for UI and 0.4 million for TANF. ${ }^{28}$

Putting this all together, there are several important observations about the social safety net for low-income households going into the Great Recession. First, with welfare reform and the expansion of the EITC, the safety net for low-income households with children has been transformed from one providing out-of-work assistance into one supporting in-work assistance. Second, a large and growing share of the cost of the social safety net is accounted for by public health insurance (Congressional Budget Office, 2013). Third, the stimulus expanded significantly the core programs aimed at protecting income from earnings losses.

\section{THE CYCLICALITY OF POVERTY}

Here we present results on the relationship between economic cycles and child poverty. We explore how the cyclicality varies as we move up the income to poverty distribution and we explore the role of the social safety net in mitigating against labor market fluctuations. Our empirical strategy exploits variation in the timing and severity of cycles across states to estimate the effect of labor market conditions on child poverty, controlling for fixed state characteristics and common shocks. We measure the business cycle using the state unemployment rate and estimate a basic state panel fixed effects model using annual data covering 2000 through 2014:

(1) $y_{s t}=\beta U R_{s t}+\alpha_{s}+\delta_{t}+\varepsilon_{s t}$

where $y_{s t}$ is child poverty (either the private income poverty or ATT poverty) measured for children in state $s$ and year $t . U R_{s t}$ is the state unemployment rate in state $s$ and year $t$; and equation (1) also controls for state and year fixed effects, $\alpha_{s}$ and $\delta_{t}$ respectively. We cluster the standard errors at the state level, and the regressions are weighted using the relevant denominator (the CPS total weighted population of children in the state-year cell). Below, we consider the robustness to alternative measures of the economic cycle, to adding time-varying state policies $\left(Z_{s t}\right)$ as well as to adding lags

\footnotetext{
${ }^{28}$ Given the focus on child poverty, the results for Social Security may be surprising. But recall that poverty is a "family," or as measured by us, a household measure and evidently many households with children also contain elderly (or to disabled) individuals receiving income from Social Security old age or disability programs.
} 
of the unemployment rate and state linear trends and individual controls.

\section{A. Main Findings}

Our main results are presented in Table 2. The first four columns present results for the child private income poverty and the second four columns present results for child ATT poverty. To explore the impacts of the cycle at different points of the income to poverty distribution, we present models for the share of children with (private or ATT) income below 50 percent, 100 percent, 150 percent and 200 percent of the poverty level. We use the Historical SPM as the poverty threshold (Fox et al 2015a). Reported in Table 2 is the estimate of the coefficient $\beta$ which captures the extent to which within-state over-time changes in poverty respond to within-state over-time changes in the state unemployment rate.

The first thing to note is that all of the coefficients in Table 2, for both private income poverty and ATT poverty, are positive and statistically significant, showing a high degree of cyclicality of child poverty consistent with the existing literature (Bitler and Hoynes 2010, 2016; Blank, 1989, 1993; Blank and Blinder, 1986; Blank and Card, 1993; Cutler and Katz, 1991; Freeman, 2001; Gunderson and Ziliak, 2004; Hoynes, Page, and Stevens, 2006; Meyer and Sullivan, 2011). Our estimates here update that previous work using data through the Great Recession, focus on child poverty, and contrast before-tax-and-transfer and after-tax-and-transfer poverty.

Looking at the first four columns (for child PI poverty), the results show that a one percentage point increase in the unemployment rate leads to a 0.9 percentage point increase in the probability that private income is below 100 percent of poverty for a 4.1 percent effect (relative to mean child PI poverty of 21.2 percent). The sensitivity of child private income poverty to changes in unemployment is the largest at the bottom of the distribution and decreases as we move up to higher poverty levels. The percent impacts of a one percentage point increase in unemployment rate are 4.8 percent for less than 50 percent of poverty, and 4.1, 3.0 and 2.3 for less than 100 percent, 150 
percent, and 200 percent of poverty, respectively. ${ }^{29}$

Columns 5 through 8 present similar models for child ATT poverty. Before comparing the results, the difference in the mean poverty rates illustrates the importance of the social safety net for low income households. For example, 10.7 percent of children have private income below 50 percent of poverty while a much lower 3.1 percent of children have ATT income below 50 percent of poverty. For 100 percent of poverty, 21.2 percent of children have private income below this level compared to 11.4 based on ATT income. The differences narrow as we move higher in the incometo-poverty distribution (32.6 percent versus 25.5 percent for 150 percent of PI and ATT poverty, and 43.2 percent versus 41.7 percent for 200 percent of PI and ATT poverty). This "tilting" of the income-to-poverty gradient reflects the high levels of various safety-net program benefits and tax credits at the lowest income levels and the potentially offsetting effects of taxes and non-cash benefits for the higher income levels. ${ }^{30}$

Comparing the results on the cyclicality of PI poverty (columns 1-4) and ATT poverty (columns 5-8), we see a strong evidence for the safety net in protecting income, particularly at the lowest income levels. For deep poverty (income below 50 percent of the poverty threshold), the results show that a one percentage point increase in the unemployment rate leads to a 0.2 percentage point increase in the level of ATT poverty, compared to the 0.5 percentage point increase in PI poverty. For 100 percent of poverty, the results show that a one percentage point increase in the unemployment rate leads to a 0.5 percentage point increase in ATT poverty, compared to a 0.9 percentage point increase in PI poverty. This reduction in the cyclicality of poverty is an illustration of the magnitude by which the social safety net provides protection against shocks to earnings and

\footnotetext{
${ }^{29}$ The point estimates increase as we move up the income distribution (across columns 1-4), but given that the baseline rates vary across the multiples of poverty, it is more appropriate to use the percent impacts (which are defined as the estimated coefficients divided by the mean of the dependent variables) to compare estimates as we move up the income-to-poverty distribution.

${ }^{30}$ To be clear, the poverty thresholds are identical between the PI and ATT measures. However, the relevant adjustments to private income will be positive for some (reflecting the value of cash and non-cash benefits as well as the value of tax credits such as the EITC) and negative for others (reflecting the effect of taxes).
} 
income. These results illustrate our main findings: the social safety net mitigates the income loss due to the Great Recession (and the much less severe 2001 recession), and reduces in particular the exposure for those at the lowest income-to-poverty levels. ${ }^{31}$

Figure 5 illustrates some of the variation underlying these regression estimates. The figure provides a scatterplot where the $\mathrm{x}$-axis shows the change in the state unemployment rate (UR, as a share) and the y-axis shows the change in child PI (100 percent) poverty (black filled circle) and child ATT (100 percent) poverty (blue open circle). Each point is a state's pair of values, and we plot the changes in UR and poverty over the Great Recession (peak over 2006 to 2008 to trough over 2009 to 2011). ${ }^{32}$ We also provide a best-fit line (using the child population in each state as weights) of these points. ${ }^{33}$ There are several things to point out with the figure. First, there is substantial variation in the severity of the labor market shock in the Great Recession across states - for example North Dakota, Alaska, and Nebraska experienced an increase in the UR of less than 1.5 percentage points, while Alabama, California, Florida and Nevada had increases of more than 5.5 percentage points. It is this variation in the unemployment rates (as well as the year-to-year timing of the changes) that provides the identification in our model. Second, and importantly, the figure compellingly helps to visualize the effect that the social safety net plays in mitigating the increases in poverty from the Great Recession. The slope of the line for private income poverty is much steeper (dashed line) than the slope for ATT poverty (solid line). Thus, the relationship between the size of the shock and the resulting change in child poverty is significantly lessened by incorporating the stabilizing effects of the social safety net. In both cases the relationship between changes in the

\footnotetext{
${ }^{31}$ When comparing PI to ATT poverty for the same poverty cutoff (e.g., 100 percent of poverty), we find it most useful to compare the percentage point effects (i.e., estimates of $\beta$ ). This allows for the direct comparison of how many children would be moved into poverty (or 50 percent of poverty, etc.) and how that compares with and without the tax-and-transfer safety net.

${ }^{32}$ Because of small sample sizes in some states, we combine three years of data for the peak and trough - in particular the change is from the weighted average for 2006-2008 to the weighted average for 2009-2011. This is the same combination of years as we used above in Figures 3 and 4.

${ }^{33}$ The slope of this best fit line essentially captures the coefficient estimate presented in panel B of Table 2. It is not identical because here we have a single "long difference" and the table uses data from 2000 through 2014.
} 
unemployment rates and changes in poverty is positive, but the correlation is larger for PI poverty compared to ATT poverty.

To explore the role of the social safety net further, Table 3 separates out the public assistance safety net and the social insurance safety net. Columns $1-4$ repeat the results for private income poverty and columns 5-8 add social insurance (or, more accurately, all non-means-tested taxes and transfers, which excludes the EITC and the CTC and refundable additional CTC). Columns 9-12 then add means-tested tax and transfer programs, arriving at ATT poverty. ${ }^{34}$ Table 3 shows the expected pattern in terms of the point estimates. As social insurance payments are added, the cyclicality of income to poverty decreases at all levels, though modestly. Adding public assistance and tax credits, in contrast, leads to a substantial decrease in cyclicality at 50 percent and 100 percent poverty (with smaller changes at the higher income-to-poverty levels).

To explore how these results vary across different groups, Table 4 presents ATT 100 percent poverty for demographic subgroups. We define subgroups based on characteristics of the household head (in most cases the parent) including marital status, race/ethnicity, and immigrant status (here, of the household head or their spouse). Prior work shows that racial and ethnic minorities are more likely to suffer labor market shocks (e.g., Hoynes, Miller, and Schaller, 2012). Additionally, singleheaded households and racial and ethnic minorities have higher baseline poverty rates. Importantly, for immigrants, another issue is that a large share of the safety net is either unavailable to them (unauthorized immigrants) or access is more limited (authorized immigrants). ${ }^{35}$ Given all of this, we would expect ATT poverty to be more responsive for households headed by non-Hispanic blacks and Hispanics than for non-Hispanic white headed households, and for households with single versus married heads. But we would also expect the safety net to be less responsive and less effective at

\footnotetext{
${ }^{34}$ Social insurance includes Social Security, UI, worker's compensation, and veterans payments. Public assistance for this purpose includes SNAP, the National School Lunch Program, SSI, TANF and GA, housing subsidies, and LIHEAP as well as the tax credits EITC, CTC, Additional CTC, and other credits.

${ }^{35}$ This is particularly the case for those who entered the country after August 1996, due to the provisions of PWRORA and the IRCA act.
} 
mitigating shocks for households headed by immigrants or with an immigrant spouse (compared to households with native heads/spouses), due to their more limited access to the safety net.

The findings in Table 4 are consistent with these predictions. A one percentage point increase in the unemployment rate leads to larger increases in poverty for children whose head of household is single (compared to married), and for children of black and Hispanic household heads (compared to children of white heads) ${ }^{36}$ Most dramatic, however, is the comparison of children of native and children of immigrant household heads/spouses. The cyclical responsiveness of poverty for children of immigrant heads/spouses is larger in absolute and percentage terms than that for children of natives, for both the PI and ATT measures. Even more striking, adding in the income from the social safety net has no mitigating effect - in fact a one percentage point increase in the unemployment rate leads to a similar 1.2 percentage point increase in both PI and ATT poverty. Appendix Table 2 shows the results for PI poverty and ATT poverty for the subgroups in columns 1-5 of Table 4, and the only other group where the cyclicality of poverty does not significantly decrease when we include taxes and transfers in the measure of income is Hispanics. Although not shown here, this same pattern for children of immigrant heads/spouses is evident for extreme poverty as well.

\section{ROBUSTNESS}

Here we explore the sensitivity of our main findings to two changes to our poverty definition as well as examine the sensitivity of our results to the basic model specification.

\section{Sensitivity to Alternative Poverty Measures}

. Our baseline results are based on our after-tax-and-transfer poverty using the Historical SPM thresholds (Fox et al., 2015a). We compare these results to those using two different absolute poverty thresholds, our version of the anchored SPM thresholds (Wimer et al., 2013) and the official poverty thresholds. We also explore the cyclicality of a relative poverty measure. To do so, we adopt the poverty definition used by the OECD: a person is poor if their income is below 60 percent of the

\footnotetext{
${ }^{36}$ The percentage effects however are smaller for the more disadvantaged groups, given their much higher average poverty rates.
} 
median of household-equivalized income. This threshold is recalculated each year and thus reflects relative income inequality rather than an absolute measure. The results for PI and ATT 100 percent poverty across these 4 measures for the thresholds are presented in Table 5. Looking across the columns, we find a remarkable consistency in the cyclicality of poverty across the different measures, in absolute and percent terms. Additionally, across the measures we find very similar effects of the social safety net (comparing private income to ATT poverty). Figure 6 illustrates this robustness more fully, by presenting these alternative measures for the four different income to poverty cutoffs (the estimates and standard errors are reported in Appendix Table 3). Across these four panels, our main findings stand out. The social safety net mitigates the effects of cyclical downturns, particularly at the lower end of the income distribution (50 percent and 100 percent of poverty). This holds regardless of whether we use the Historical SPM thresholds, the anchored SPM thresholds, or official poverty thresholds. It also holds for a quite different construct, the OECD relative poverty thresholds.

Table 6 explores the sensitivity of our results to the treatment of costs and benefits of medical care and insurance. Our baseline measure of resources used to construct ATT poverty (see the definitions of the poverty measure resource definitions in Appendix Table 1) does not include the benefits of health insurance (public or employer-provided) nor does it include the out of pocket medical costs (or other fixed costs of work). Table 6 presents two alternatives prominent in the literature. First, we adopt the Census approach used for most of the period prior to the introduction of the Census SPM (experimental poverty measure as suggested by the National Academy of Sciences). This adds to ATT income the fungible value of Medicaid (and Medicare and includes the value of the employer contribution to HI premiums). Second, we use the approach in the Census SPM and deduct from ATT income out of pocket medical costs (here we also deduct work-related expenses including child care costs as is implemented in the SPM). The results, for 100 percent poverty using both the historical and anchored SPM thresholds, are shown in Table 6. By looking at the means of the 
dependent variable across the columns in the table, it is clear that how one treats the costs and benefits of medical care and insurance makes a difference in the level of the measured child poverty rates. However, the table shows clearly that our core finding concerning the cyclicality of poverty, quantitatively and qualitatively, is little changed by how we treat medical care. Figure 7 expands this

analysis to illustrate how these results vary across income-to-poverty thresholds (the full set of coefficients and standard errors, including those for the ATT poverty with anchored SPM thresholds are presented in Appendix Table 4). The figure confirms our main finding that the percent effects of an increase in unemployment decline as we move up the income-to-poverty distribution.

\section{Sensitivity to Alternative Model Specifications}

First, we explore the sensitivity to adding controls for demographic characteristics, state-level time varying policies, and state linear trends to our relatively parsimonious estimation model. The results are shown in Appendix Table 5. Our first set of robustness (panel B) turns to individual regressions and adds controls for the head's characteristics including dummies for single years of age; dummies for race/ethnicity (Hispanic, white non-Hispanic, black non-Hispanic, other nonHispanic); a dummy for marital status (head is married); a dummy for the head being male; and dummies for the head's education being high school graduate, some college, and college graduate. While these need not look identical to our aggregate regressions, these individual controls make little difference to our findings. We also explore how state policy choices in Medicaid (eligibility limits for pregnant women and children), state-level EITCs, the average UI replacement rate (Kuka, 2016), TANF (the guarantee), and the real level of the binding minimum wage affect our estimates.

Controlling for these important poverty determinants has little substantive effect on our estimates of cyclicality of any of our poverty measures (panel C). Similarly, including state linear trends does not significantly affect our estimates (panel D).

Next we explore the sensitivity to our choice of the unemployment rate as the measure of the cycle. Appendix Table 6 presents our baseline results, followed by panel B with the employment to 
population ratio (EPOP) as the measure of the state-year cycle, and panel $\mathrm{C}$ with real chained GDP per capita as the measure of the cycle. We present results for PI and ATT poverty and for the four cuts of income to poverty. Broadly speaking, the qualitative findings are similar regardless of whether we use the unemployment rate or EPOP as our measure of the cycle. All coefficients for the effect of the business cycle on poverty are countercyclical and highly statistically significant (the coefficients on the EPOP and GDP per capita are negative, indicating a strengthening of the labor market leads to a reduction in poverty), and the magnitudes of the percent impacts are strikingly similar for the unemployment rate and EPOP (in absolute value) ${ }^{37}$ The results show that GDP per capita is not a statistically significant determinant although all but one of the signs are consistent with those for the unemployment rate and EPOP; when the coefficient for the unemployment rate is positive, that for the GDP is negative 7 of 8 times and that for EPOP is always negative. We also explored including the Census's imputed tax measures instead of assigning the TAXSIM values, not weighting by the population of children, and using an alternate sharing unit, the smallest related family unit in Census terms, the subfamily. None of these additional changes (not shown) matter substantively.

Our final robustness check looks at effects of adding lags (one or two years) of the unemployment rate to our main specification (Appendix Table 7). Here, the cumulative effect is relatively unchanged, and the bulk of the effects are on the contemporaneous level of the unemployment rate.

In sum, our main results are robust to alternative definitions for resources, poverty thresholds, the measure of the economic cycle, and the regression specification.

\section{CONCLUSION}

\footnotetext{
${ }^{37}$ A percent impact of " $\mathrm{x}$ " implies that a one percentage point increase in UR (or EPOP) leads to an $\mathrm{x}$ percent increase in the poverty rate. One might be worried that these two marginal effects (a one percentage point change in UR versus a one percentage point change in EPOP) might represent very different changes, however the change in the EPOP is quite similar (although oppositely signed) from the change in the UR during the Great Recession.
} 
Beginning in 2007, the Great Recession led to unemployment rates unseen since the deep recessions of the early 1980s. At the same time, significant changes in the safety net occurred both before and during this most recent downturn. These two events make it important to explore the role of the safety net in providing protection during the Great Recession, both through the normal countercyclical response and through ARRA. We focus on child poverty, as children experience some of the highest poverty rates of any group in the United States.

We consider two child poverty measures, which differ in the way they count resources - one focuses on PI poverty and the other on ATT poverty. By comparing the response of these two poverty measures across the business cycle, we gain insight into the role played by the social safety net in protecting children's well-being against economic shocks. We use CPS data covering the period 2000 through 2014 and estimate state-year panel data models where we measure state business cycles using unemployment rates. Our results are identified using the significant and sizeable variation in the timing and severity of the business cycle across states.

We find that child poverty is cyclical and the cyclicality is larger in magnitude (in percent terms) at lower points in the income-to-poverty ratio distribution. This finding has been shown in other work to be true historically and continues to be evident in the Great Recession. We also find that the safety net as a whole provides significant protection, as the cyclicality of after-tax-andtransfer poverty is significantly lower than the cyclicality of private income poverty. While our main specifications rely on quasi-relative poverty thresholds as in the Historical SPM (Fox et al., 2015a), we find that the findings are quite robust across absolute measures such as the official poverty thresholds and anchored SPM thresholds (Wimer et al., 2013), and even when using the OECD's relative poverty threshold. Moreover, our results are robust to how we treat the value of health insurance and medical expenses when we calculate household resources, and to a variety of alternative model specifications. Lastly, while we find that on average the safety net is effective at mitigating the cyclicality of child poverty, our results also show that these effects are differential 
across groups and that cyclicality of poverty is larger for children in households headed by single parents, Hispanics, and, most significantly, immigrants or those with an immigrant spouse. 


\section{REFERENCES}

Bavier, R. (2008). Reconciliation of Income and Consumption Data in Poverty Measurement. Journal of Policy Analysis and Management, 27, 40-62.

Bavier, R. (2014). Recent Trends in U.S. Income and Expenditure Poverty. Journal of Poverty Analysis and Management, 33, 700-718.

Bitler, M., and Hoynes, H.W. (2010). The State of the Safety Net in the Post-Welfare Reform Era. Brookings Papers on Economic Activity, Fall, 71-127.

Bitler, M., and Hoynes, H.W. (2015). Heterogeneity in the Impact of Economic Cycles and the Great Recession: Effects Within and Across the Income Distribution, American Economic Review Papers and Proceedings, 105, 154-160.

Bitler, M., and Hoynes, H.W. (2016). The More Things Change the More They Stay the Same? The Safety Net and Poverty in the Great Recession. Journal of Labor Economics, 34, S403-S444.

Blank, R. (1989). Disaggregating the Effect of the Business Cycle on the Distribution of Income. Economica, 56, 141-163.

Blank, R. (1993). Why Were Poverty Rates so High in the 1980s?. In D.B. Papadimitriou and E.N. Wolff, (Eds.), Poverty and Prosperity in the Late Twentieth Century. St Martin's Press. London: Macmillan Press.

Blank, R. (2002). Evaluating Welfare Reform in the United States. Journal of Economic Literature, 40, 1105-1166.

Blank, R. (2008). Presidential Address: How to Improve Poverty Measurement in the United States. Journal of Policy Analysis and Management, 27, 233-254.

Blank, R., and Blinder, A. (1986). Macroeconomics, Income Distribution, and Poverty. In S. Danziger and D. Weinberg, (Eds.), Fighting Poverty: What Works and What Doesn't. Cambridge, MA: Harvard University Press.

Blank, R., and Card, D. (1993). Poverty, Income Distribution and Growth: Are They Still Related? Brookings Papers on Economic Activity 2, 285-339.

Brooks-Gunn, J. and Duncan, G. (1997). The Effects of Poverty on Children. The Future of Children 7, 55-71.

Burkhauser, R. (2009). Deconstructing European Poverty Measures: What Relative and Absolute Scales Measure. Professional Practice, Journal of Policy Analysis and Management, 28, 715-725.

Centers for Medicare and Medicaid Services (2010). Unpublished Age and Gender Tables, Retrieved July 7, 2016 from https://www.cms.gov/Research-Statistics-Data-and-Systems/Statistics-Trends-andReports/NationalHealthExpendData/Age-and-Gender.html.

Centers for Medicare and Medicaid Services (2013). Medicare and Medicaid Statistical Supplement, 2013 Edition. Retrieved September 5, 2016 from https://www.cms.gov/research-statistics-data-andsystems/statistics-trends-and-reports/medicaremedicaidstatsupp/2013.html. 
Citro, C. and Michael, R. (Eds.) (1995). Measuring Poverty: A New Approach. Washington D.C.: National Academy Press.

Congressional Budget Office (2013). Growth in Means-Tested Programs and Tax Credits for LowIncome Households. (CBO Report 43934). Washington, DC.

Congressional Budget Office (2014). The Distribution of Household Income and Federal Taxes, 2011. (CBO Report 49440). Washington, DC.

Congressional Research Service (2012). Low Income Assistance Programs: Trends in Federal Spending. (CBO Report R41823), Washington, DC.

Cutler, D., and Katz, L. (1991). "Macroeconomic Performance and the Disadvantaged”, Brookings Papers on Economic Activity 1, 1-74.

Floyd, I., Pavetti, L., and Schott, L. (2015). TANF Continues to Weaken as a Safety Net. Center for Budget and Policy Priorities.

Fox, L., Wimer, C., Garfinkel, I., Kaushal, N., and Waldfogel, J. (2015a). Waging War on Poverty: Poverty Trends Using a Historical Supplemental Poverty Measure. Journal of Policy Analysis and Management, 34, 567-592.

Fox, L., Wimer, C., Garfinkel, I., Kaushal, N., Nam, J., and Waldfogel, J. (2015b). Trends in Deep Poverty from 1968 to 2011: The Influence of Family Structure, Employment Patterns, and the Safety Net. Rusell Sage Journal, 1, 14-34.

Fraker, T.M., Martini, A.P., Ohls, J.C., Ponza, M., and Quinn, E.A. (1992). The Evaluation of the Alabama Food Stamp Cash-Out Demonstration: Volume 1 Recipient Impacts. Mathematica Policy Research, Inc.

Freeman, R. (2001). The Rising Tide Lifts...? In Sheldon Danziger and Robert Haveman (Eds.), Understanding Poverty (pp. 97-126). Cambridge, MA: Harvard University Press.

Gruber, J. (1997). Health Insurance for Poor Women and Children in the U.S.: Lessons from the Past Decade. In James Poterba (Ed.), Tax Policy and the Economy, Volume 11. Cambridge, MA: National Bureau of Economic Research.

Gundersen, Craig and James Ziliak. (2004). "Poverty and Macroeconomic Performance across Space, Race, and Family Structure,” Demography, 41:1, 61-86.

Hardy, B., Smeeding, T., and Ziliak, J. (2015). The Changing Safety Net for Low-Income Parents and Their Children: Structural or Cyclical Changes in Income Support Policy. Mimeo.

Hotz, J. and Scholz, J.K. (2003). The Earned Income Tax Credit. In Robert Moffitt, (Ed.) MeansTested Transfer Programs in the United States (pp. 141-197). The University of Chicago Press and NBER.

Hoynes, H.W., Miller, D., and Schaller, J. (2012). Who Suffers in Recessions and Jobless Recoveries? Journal of Economic Perspectives, 26, 27-48.

Hoynes, H.W., Page, M.E. and Stevens, A.H. (2006). Poverty in America: Trends and Explanations. Journal of Economic Perspectives, 20, 47-68. 
Hoynes, H.W., and Rothstein, J. (2016). Tax Policy Toward Low Income Families. Working Paper 22080. Cambridge, MA: National Bureau of Economic Research.

Hoynes, H.W., and Schanzenbach, D.W. (2009). Consumption Reponses to In-Kind Transfers: Evidence from the Introduction of the Food Stamp Program. American Economic Journal: Applied Economics, 1, 109-139.

Hoynes, H.W., and Schanzenbach, D.W. (2016). U.S. Food and Nutrition Programs. In R. Moffitt (Ed.) Means-Tested Transfer Programs in the U.S, University of Chicago Press.

Internal Revenue Service (2016). Statistics of Income-1990-2013 Individual Income Tax Returns. (Publication 1304). Retrieved July 7, 2016 from http://www.irs.gov/uac/soi-tax-stats-individualincome-tax-returns-publication-1304-complete-report\#_tbla.

Kuka, E. (2016). Quantifying the Benefits of Social Insurance: Unemployment Insurance and Health, Working Paper.

Larrimore, J., Burkhauser, R., and Armour, P. (2015). Accounting for Income Changes over the Great Recession Relative to Previous Recessions: The Impact of Taxes and Transfers. National Tax Journal, 68, 281-318.

Meyer, B., and Sullivan, J. (2011). Consumption and Income Poverty over the Business Cycle. Research in Labor Economics 32, 51-82.

Meyer, B., and Sullivan, J. (2012). Identifying the Disadvantaged: Official Poverty, Consumption Poverty, and the New Supplemental Poverty Measure, Journal of Economic Perspectives, 26, 11136.

Meyer, B., Mok, W., and Sullivan, J. (2009). The Under-Reporting of Transfers in Household Surveys: Its Nature and Consequences. Working Paper 15181. Cambridge, MA: National Bureau of Economic Research.

Moffitt, R. (1983). “An Economic Model of Welfare Stigma,” American Economic Review 73(5), $1023-35$.

Moffitt, R. (2012). The Reversal of the Employment-Population Ratio in the 2000s: Facts and Explanations. Brookings Papers on Economic Activity, Fall, 201-251.

Moffitt, R. (2015). The Deserving Poor, the Family, and the U.S. Welfare System. Demography, 52, 729-749.

Organisation for Economic Cooperation and Development (2015) In It Together: Why Less Inequality Benefits All. Paris: OECD Publishing.

Ohls, J.C., Fraker, T.M., Martini, A.P., and Ponza, M. (1992). The Effects of Cash-Out on Food Use by Food Stamp Program Participants in San Diego. U.S. Department of Agriculture, Food and Nutrition Service, Office of Analysis and Evaluation: Washington, DC.

Oliviera, V. (2016). The Food Assistance Landscape FY 2015 Annual Report. (Economic Research Service Economic Information Bulletin 150). U.S. Department of Agriculture: Washington, DC. 
Parker, J., and Vissing-Jorgensen, A. (2009). Who Bears Aggregate Fluctuations? Estimates and Implications for Consumption Inequality. American Economic Review Papers and Proceedings, 99, 399-405.

Parker, J., and Vissing-Jorgensen, A. (2010). The Increase in Income Cyclicality of High-Income Households and Its Relation to the Rise in Top Income Shares. Brookings Papers on Economic Activity, 41, 1-55

Rothstein, J. (2011). Unemployment Insurance and Job Search in the Great Recession. Brookings Papers on Economic Activity, 43, 132-210.

Sherman, A., and Trisi, D. (2015). Safety Net for Poorest Weakened after Welfare Law but Regained Strength in Great Recession, at Least Temporarily, A Decade after Welfare Overhaul, More Children in Deep Poverty. Center for Budget and Policy Priorities.

Short, K. (2011). The Research Supplemental Poverty Measure: 2010. (Current Population Reports P60-241). Washington, DC: U.S. Census Bureau.

Short, K. (2013). The Research Supplemental Poverty Measure: 2012. (Current Population Reports P60-247). Washington, DC: U.S. Census Bureau.

Short, K. (2015). The Research Supplemental Poverty Measure: 2014. (Current Population Reports P60-254). Washington, DC: U.S. Census Bureau.

Social Security Administration (2016). Monthly Statistical Snapshot May 2016, Table 2. Retrieved September 5, 2016 from https://www.ssa.gov/policy/docs/quickfacts/stat snapshot/.

U.S. Census Bureau. (2015). Income Poverty and Health Insurance Coverage in the United States: 2014. (Current Population Reports P60-252). Washington, DC.

U.S. Department of Agriculture, Food and Nutrition Service. (2016a). Supplemental Nutrition Assistance Program Participation and Costs. Retrieved July 7, 2016 from www.fns.usda.gov/sites/default/files/pd/SNAPsummary.pdf.

U.S. Department of Agriculture, Food and Nutrition Service. (2016b). "Federal Cost of School Food Programs.” Retrieved July 7, 2016 from www.fns.usda.gov/sites/default/files/pd/cncost.pdf.

U.S. Department of Health and Human Services, Office of Family Assistance (2016). TANF Financial Data - FY 2010. Retrieved July 7, 2016 from www.acf.hhs.gov/sites/default/files/ofa/2010_tanf_data_with_states.pdf.

U.S. Department of Labor, Employment \& Training Administration. (2016). Benefits Paid All Programs, Most Frequently Requested Statistics. Retrieved July 7, 2016 from oui.doleta.gov/unemploy/frs.asp.

U.S. Government Accountability Office. (2007). Food Stamp Program. (GAO Report GAO-07-465). Washington, DC.

U.S. House of Representatives. (1996). Green Book: Background Material and Data on Programs Within the Jurisdiction of the House Committee on Ways and Means. Committee on Ways and Means. Washington, DC: Government Printing Office. 
Wimer, C., Fox, L., Garfinkel, I., Kaushal, N., and Waldfogel, J. (2013). Trends in Poverty with an Anchored Supplemental Poverty Measure. mimeo. 
Figure 1: Annual Unemployment Rate and Private Income Poverty and After-Tax-and-Transfer Poverty for Children

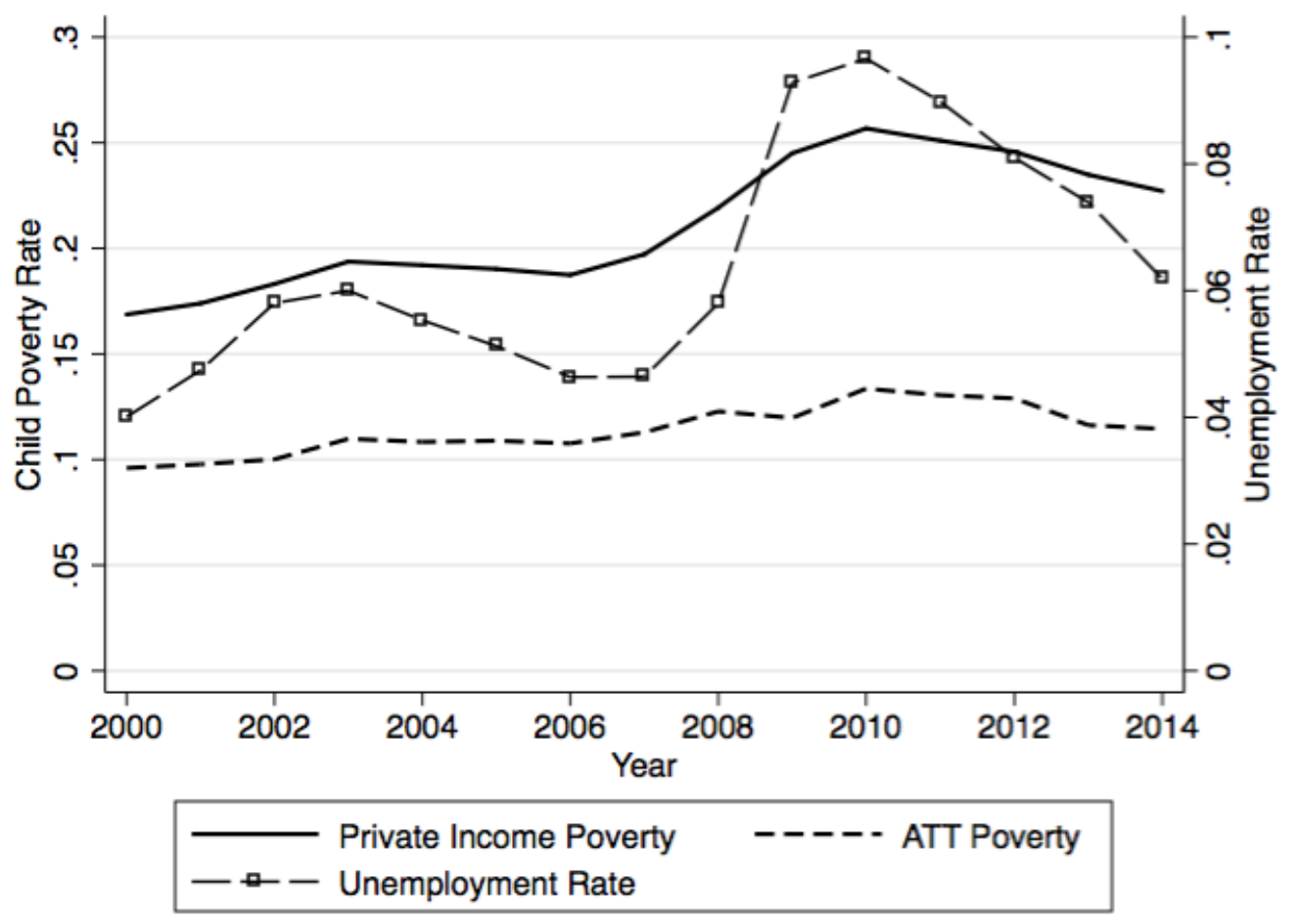

Notes: Data are from the 2000 through 2014 calendar year ASEC (poverty measures) and the Bureau of Labor Statistics (unemployment). Poverty refers to percent of children living in households with income below the Historical SPM poverty line in each calendar year, using various concepts for resources. Private income includes only wages and salaries, self-employment income, and private transfers. ATT income includes the value of public in-kind and cash transfers and nets out taxes and tax credits. 
Figure 2: Change in Average Child Household Income by Source and State in the Great Recession

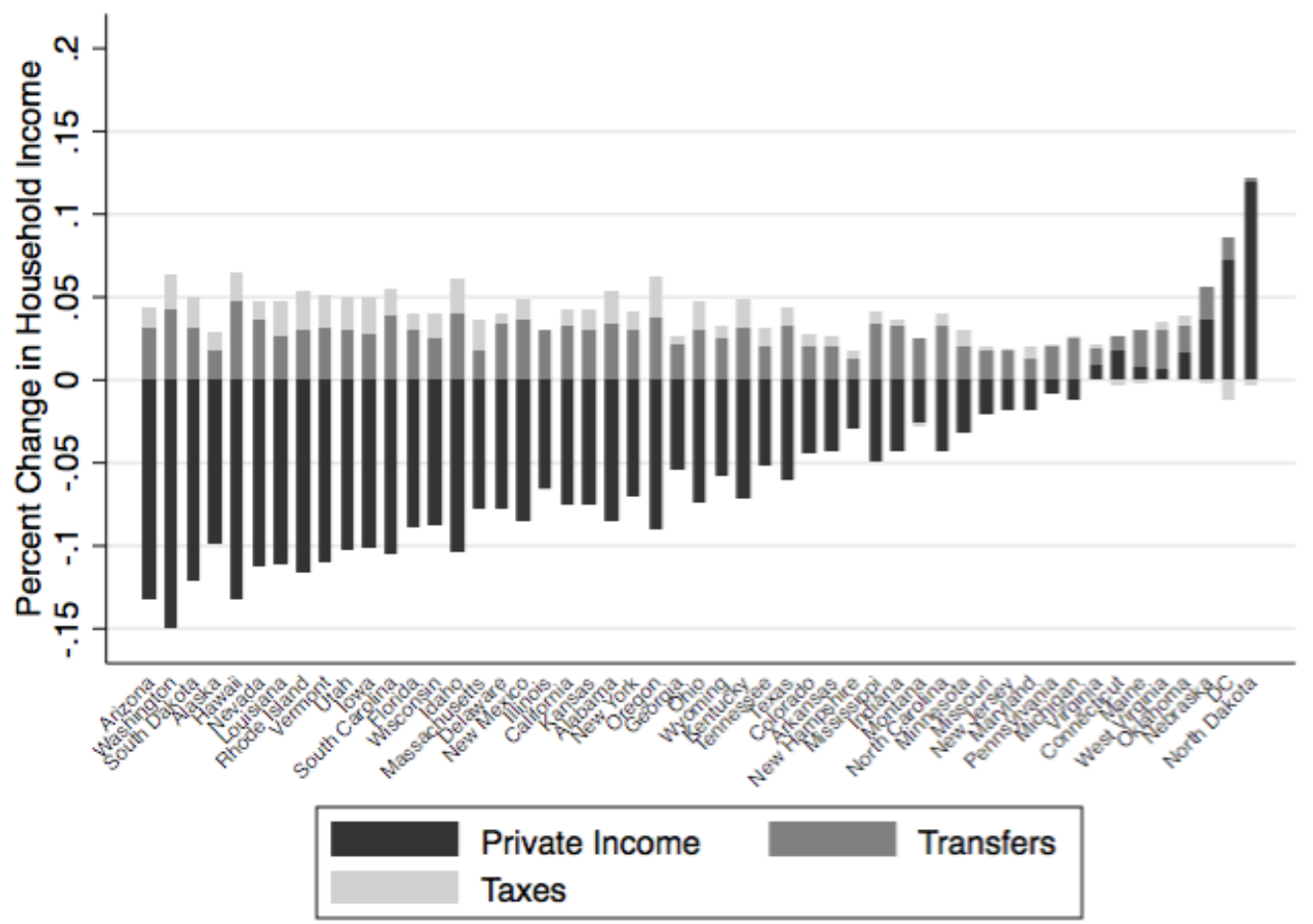

Notes: Data are from the 2006 to 2008 and 2009 to 2011 ASEC calendar years. Percent changes in sources of income for children are computed as the percent difference between the 2006 to 2008 weighted average of state household income from that source for children and the 2009 to 2011 weighted average of state household income for that source for children. 
Figure 3: Change in Private Income Poverty and After-Tax-and-Transfer Poverty during the Great Recession for Children



Notes: Data are from the 2006 to 2008 and 2009 to 2011 ASEC calendar years. Change in poverty refers to the change in the share of children in each state living in households with PI and ATT income below the Historical SPM poverty line. Changes in the share of children in poverty are computed as the difference between the 2006 to 2008 weighted average state poverty rate and the 2009 to 2011 weighted average state poverty rate. 
Figure 4: Composition of After-Tax-and-Transfer Income by Source for Children, 2010

(a) Below 50\% Poverty

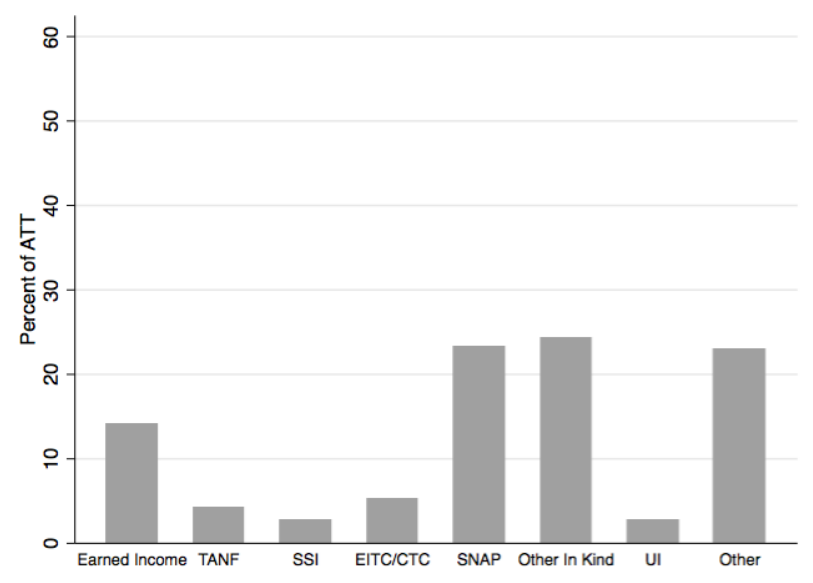

(c) Below $150 \%$ Poverty

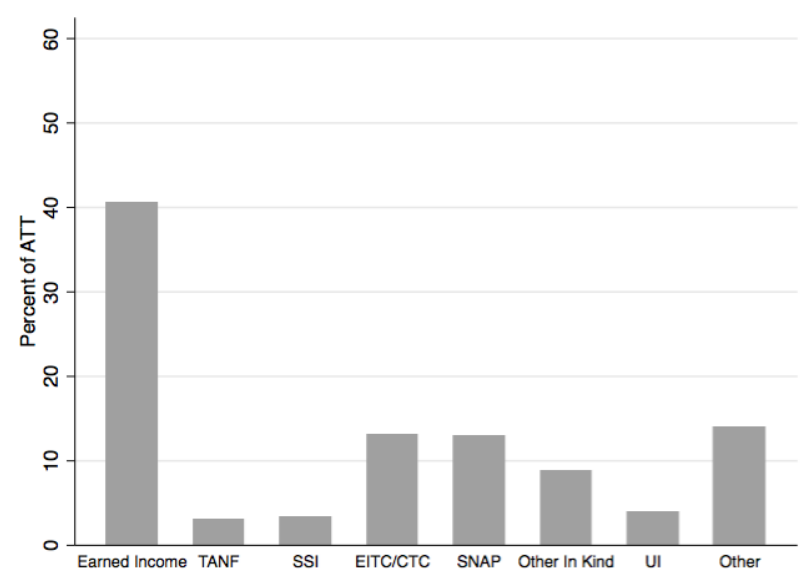

(b) Below 100\% Poverty

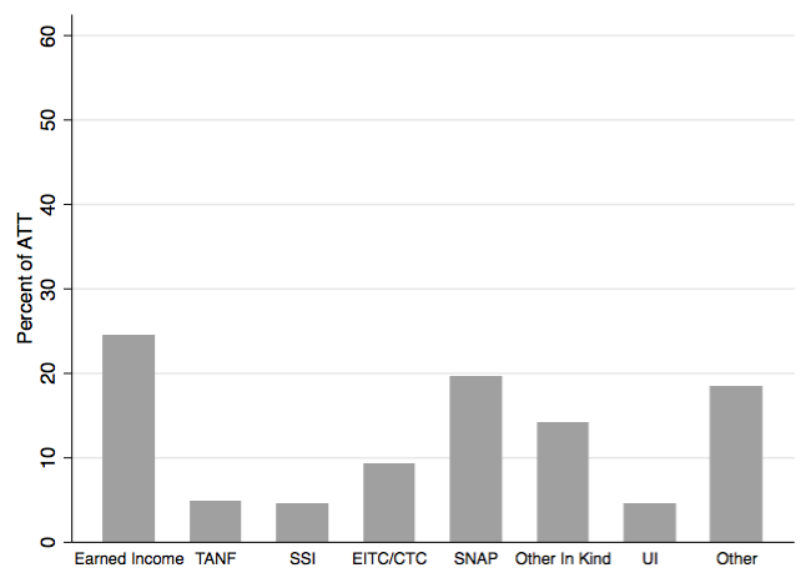

(d) Below 200\% Poverty

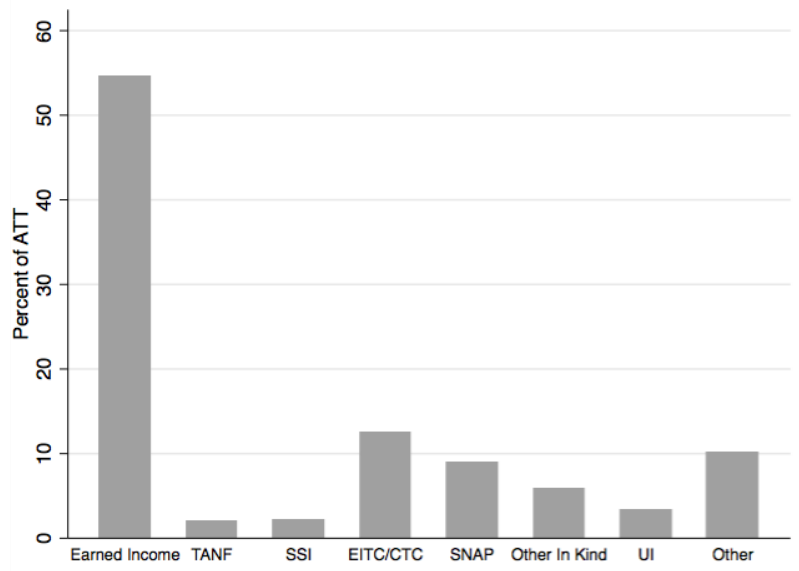

Notes: Data are from the 2010 ASEC (income from calendar year 2010). Poverty multiples refer to the sample of children living in households with income below multiples of the Historical SPM poverty line, using ATT income. The percentages sum to one hundred. Other in-kind sources are School Lunch and LIHEAP. "Other" sources of income include Social Security (Old Age and Disability benefits), veterans payments, workers' compensation, unearned private income (asset income, child support, alimony, private retirement and private disability) and federal and state taxes other than the EITC and Child Tax Credits. 
Figure 5: Change in Unemployment Rate and Child ATT Poverty in the Great Recession, by State

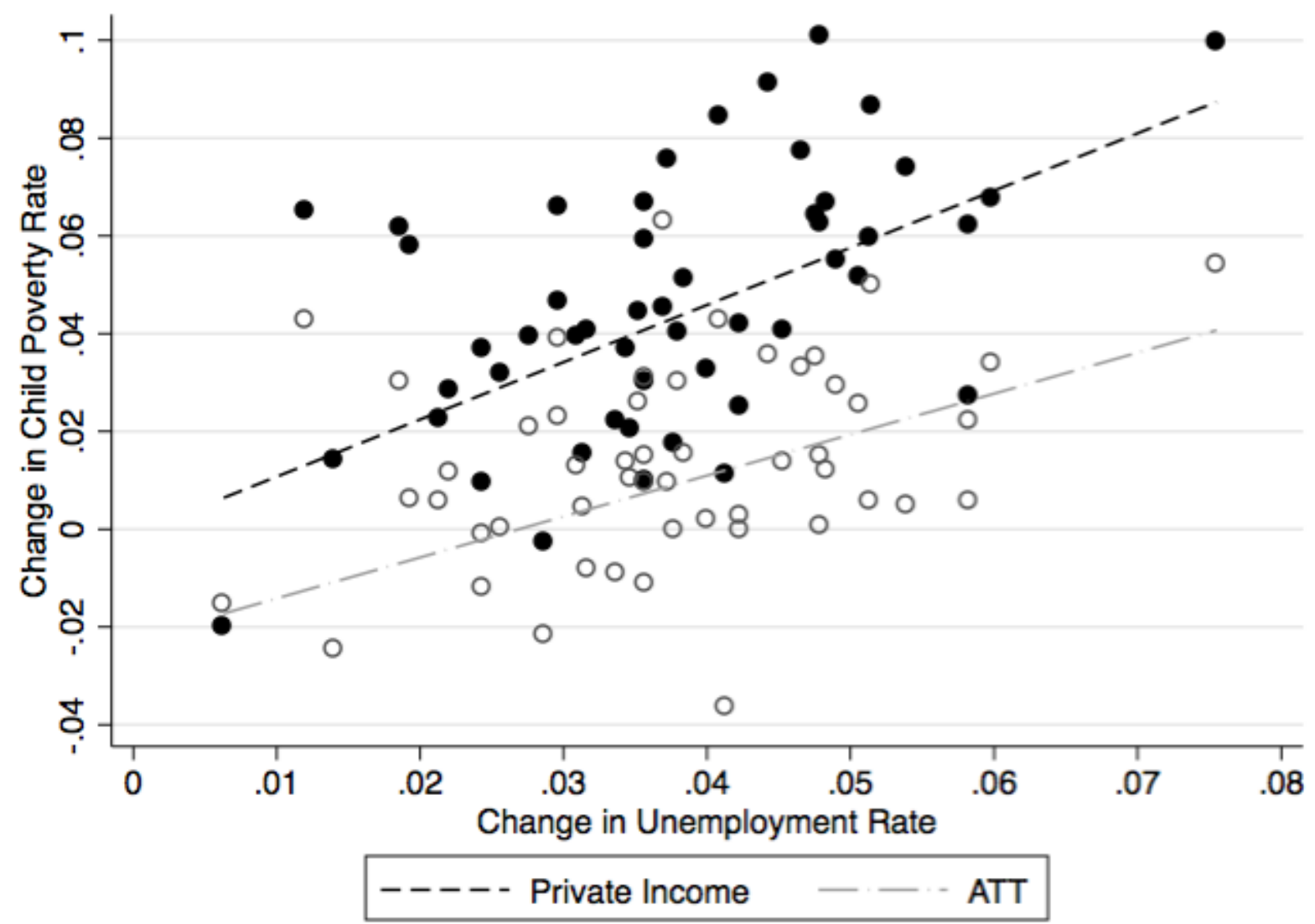

Notes: Data are from the 2006 to 2008 and 2009 to 2011 ASEC (calendar year income) and the Bureau of Labor Statistics. Poverty refers to percent of children living in households with PI or ATT income below the Historical SPM poverty line. Changes in poverty rates and unemployment rates are computed as the differences between the weighted state average child poverty and unemployment rate (as a share) for 2006 to 2008 and the weighted state average child poverty and unemployment rate (as a share) for 2009 to 2011 . 
Figure 6: Effects of Unemployment Rate on Private Income Child Poverty and After-Tax-andTransfer Child Poverty - Sensitivity to the Choice of Poverty Threshold

(a) Below 50\% Poverty

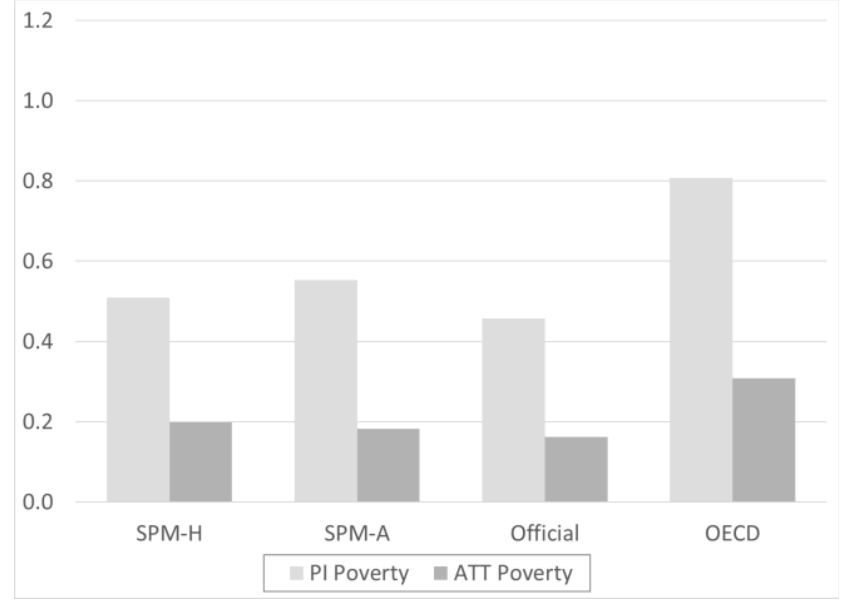

(c) Below $150 \%$ Poverty

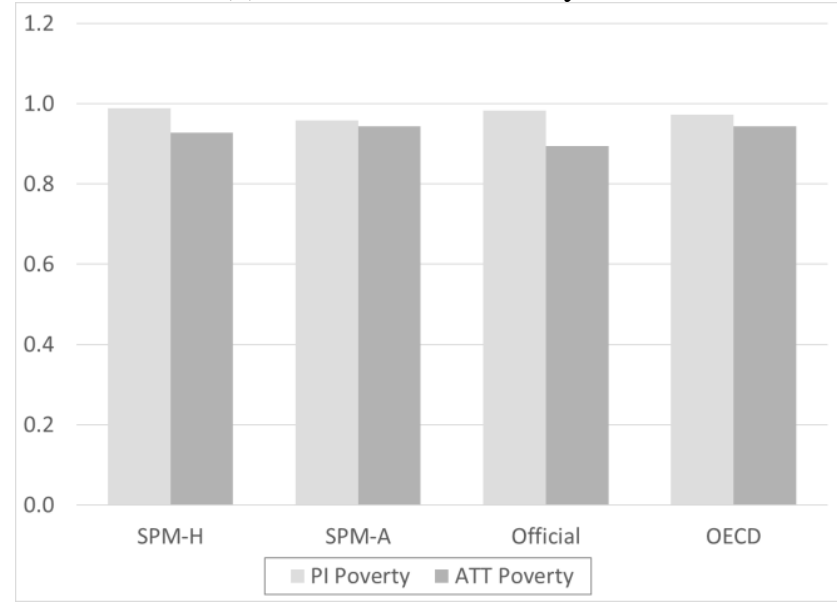

(b) Below $100 \%$ Poverty

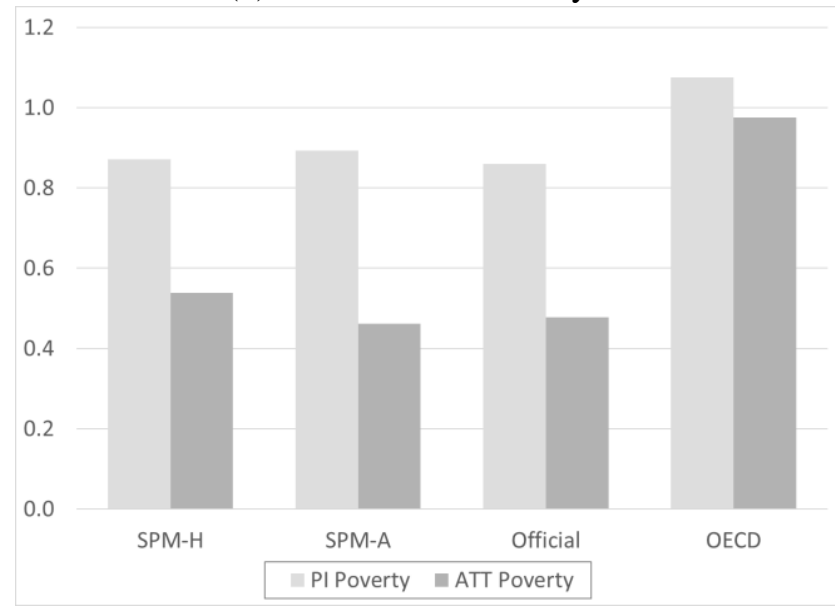

(d) Below 200\% Poverty

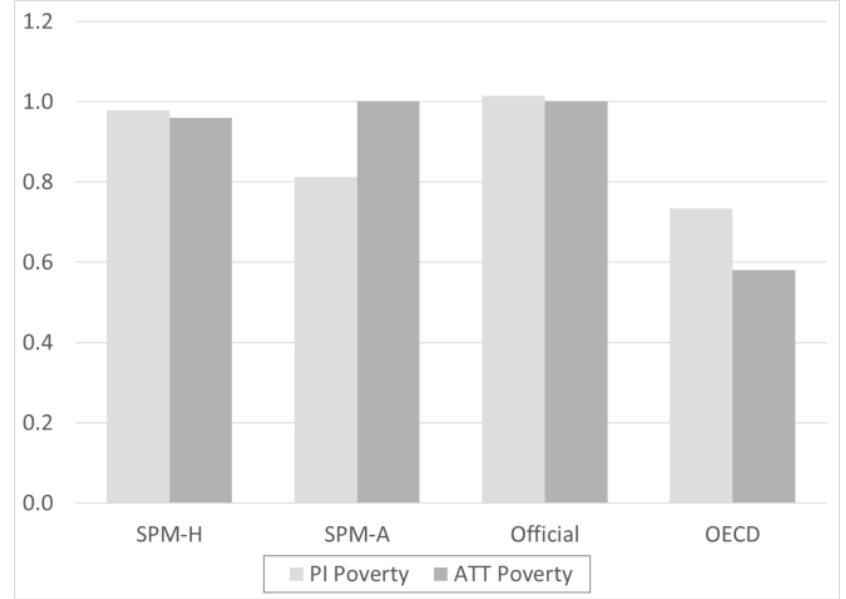

Notes: Figure shows the relationship between the unemployment rate and children having household private income or after-tax-and-transfer income below various multiples of the Historical SPM threshold, the anchored SPM threshold, the official poverty threshold and the OECD poverty threshold. Data are from the CPS ASEC calendar years 2000-2014 and are collapsed to the state by year level (weighted). 
Figure 7: Sensitivity of ATT Poverty Cyclicality to Treatment of Medical Benefits, Historical SPM Thresholds

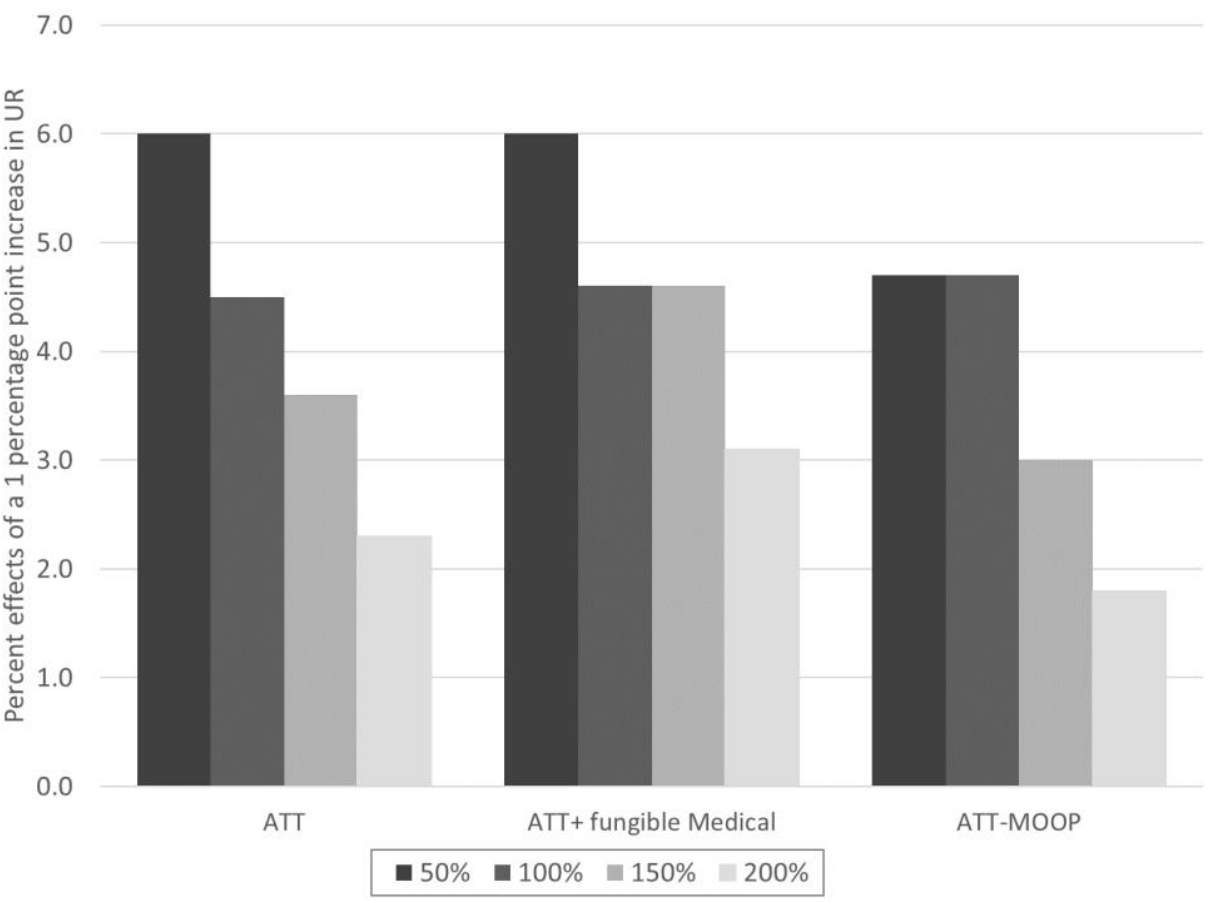

Notes: Figure shows the relationship between having household after-tax-and-transfer income below various multiples of the Historical SPM poverty threshold and the state unemployment rate, using various measures of resources to construct the poverty measures. First set of bars are percent effects using an ATT measure of resources, second set of bars are percent effects using a resource measure that adds the fungible value of Medicaid/CHIP and Medicare and the employer contribution to HI premiums to ATT resources, and the third set of bars subtracts MOOP, child care expenses, and other work expenses from ATT resources. Data are from the CPS ASEC calendar years 2000 through 2014 and are collapsed to the state by year level (weighted). All effects from regressions that include controls for state and year fixed effects, and percent effects derived by dividing the estimated coefficient on the unemployment rate by the average of the dependent variable. The regression results are weighted by the sum of the CPS weights in the cell. 
Table 1: Total Cost of Safety-Net Programs Captured in Our After-Tax-and-Transfer Income-2010

\begin{tabular}{lr}
\hline & Billions of dollars \\
\hline Public assistance, cash & \\
TANF, cash assistance & 912.4 \\
SSI, recipients<18 & 9.4 \\
Pubic assistance, food and nutrition programs & \\
SNAP & 64.8 \\
School Lunch & 9.8 \\
& \\
Tax credits & 59.6 \\
EITC & 28.5 \\
CTC (primarily higher income filers) & 27.7 \\
Additional CTC (refundable) & \\
Public assistance, other inkind & 27.3 \\
Housing (Section 8, Public Housing) & 67.2 \\
Medicaid, recipients <18 & 5.1 \\
LIHEAP & \\
Social insurance & 150.0 \\
UI (Regular, Extended, Emergency, \& STC) & \\
\hline
\end{tabular}

Notes: Table shows total spending in billions of 2010 dollars on various transfer programs and tax credits. Source for TANF cash assistance spending for FY 2010: OFA (2016); for SSI spending for children, 2010: SSA (2016); for SNAP for FY 2010: FNS (2016a); for School Lunch for FY 2010: FNS (2016b); for EITC and CTC for 2010: IRS (2016); for Housing for FY 2011 in 2011 dollars (CRS 2012); for Medicaid for 2010: CMS (2016); and for UI for 2010, ETA (2016). 
Table 2: Effects of Unemployment Rate on Private Income and After-Tax-and-Transfer Child

\begin{tabular}{|c|c|c|c|c|c|c|c|c|}
\hline \multicolumn{9}{|c|}{ Poverty } \\
\hline & \multicolumn{4}{|c|}{ Private Income Poverty } & \multicolumn{4}{|c|}{ After Tax and Transfer Poverty } \\
\hline & $<50 \%$ & $<100 \%$ & $<150 \%$ & $<200 \%$ & $<50 \%$ & $<100 \%$ & $<150 \%$ & $<200 \%$ \\
\hline UR & $\begin{array}{c}0.509 \\
(0.097)\end{array}$ & $\begin{array}{c}0.871 \\
(0.134)\end{array}$ & $\begin{array}{c}0.988 \\
(0.152)\end{array}$ & $\begin{array}{c}0.978 \\
(0.165)\end{array}$ & $\begin{array}{c}0.198 \\
(0.057)\end{array}$ & $\begin{array}{c}0.538 \\
(0.096)\end{array}$ & $\begin{array}{c}0.928 \\
(0.157)\end{array}$ & $\begin{array}{c}0.959 \\
(0.151)\end{array}$ \\
\hline$\%$ Impact & 4.8 & 4.1 & 3.0 & 2.3 & 6.3 & 4.7 & 3.6 & 2.3 \\
\hline Mean y & 0.107 & 0.212 & 0.326 & 0.432 & 0.031 & 0.114 & 0.255 & 0.417 \\
\hline Mean UR & 0.064 & 0.064 & 0.064 & 0.064 & 0.064 & 0.064 & 0.064 & 0.064 \\
\hline $\mathrm{N}$ & 765 & 765 & 765 & 765 & 765 & 765 & 765 & 765 \\
\hline
\end{tabular}

Notes: Table shows the relationship between children having household private income (columns 1-4) or after-tax-and-transfer income (columns 5-8) below various multiples of the Historical SPM poverty threshold and the state unemployment rate. Data are from the CPS ASEC calendar years 2000 to 2014 and are collapsed to the state by year level (weighted). All regressions include controls for state and year fixed effects. The results are weighted by the sum of the CPS weights in the cell. Standard errors are clustered by state and shown in parentheses.

Table 3: Effects of Unemployment Rate on Private Income and After-Tax-and-Transfer Child Poverty - Social Insurance vs. Public Assistance

\begin{tabular}{|c|c|c|c|c|c|c|c|c|c|c|c|c|}
\hline & \multicolumn{12}{|c|}{$\underline{\text { Resource measure: Priv. Income }+}$} \\
\hline & \multicolumn{4}{|c|}{$\underline{\text { Resource measure: Private Income }}$} & \multicolumn{4}{|c|}{$\underline{\text { Social Insurance }}$} & \multicolumn{4}{|c|}{$\underline{\text { Resource Measure: ATT income }}$} \\
\hline & $<50 \%$ & $<100 \%$ & $<150 \%$ & $<200 \%$ & $<50 \%$ & $<100 \%$ & $<150 \%$ & $<200 \%$ & $<50 \%$ & $<100 \%$ & $<150 \%$ & $<200 \%$ \\
\hline UR & $\begin{array}{c}0.509 \\
(0.097)\end{array}$ & $\begin{array}{c}0.871 \\
(0.134)\end{array}$ & $\begin{array}{c}0.988 \\
(0.152)\end{array}$ & $\begin{array}{c}0.978 \\
(0.165)\end{array}$ & $\begin{array}{c}0.351 \\
(0.114)\end{array}$ & $\begin{array}{c}0.806 \\
(0.138)\end{array}$ & $\begin{array}{c}0.803 \\
(0.163)\end{array}$ & $\begin{array}{c}0.910 \\
(0.156)\end{array}$ & $\begin{array}{c}0.198 \\
(0.057)\end{array}$ & $\begin{array}{c}0.538 \\
(0.096)\end{array}$ & $\begin{array}{c}0.928 \\
(0.157)\end{array}$ & $\begin{array}{c}0.959 \\
(0.151)\end{array}$ \\
\hline$\%$ Impact & 4.8 & 4.1 & 3.0 & 2.3 & 4.1 & 4.1 & 2.5 & 2.0 & 6.3 & 4.7 & 3.6 & 2.3 \\
\hline Mean y & 0.107 & 0.212 & 0.326 & 0.432 & 0.086 & 0.195 & 0.325 & 0.454 & 0.031 & 0.114 & 0.255 & 0.417 \\
\hline Mean UR & 0.064 & 0.064 & 0.064 & 0.064 & 0.064 & 0.064 & 0.064 & 0.064 & 0.064 & 0.064 & 0.064 & 0.064 \\
\hline $\mathrm{N}$ & 765 & 765 & 765 & 765 & 765 & 765 & 765 & 765 & 765 & 765 & 765 & 765 \\
\hline
\end{tabular}

Notes: Table shows the relationship between children having household private income (columns 1-4), household income and social insurance (columns 5-8), or after-tax-and-transfer income (columns 9-12) below various multiples of the Historical SPM poverty threshold and the state unemployment rate. "Social Insurance" includes all tax and transfer programs not explicitly means tested, this includes federal income taxes (except EITC and refundable CTC). Data are from the CPS ASEC calendar years 2000 to 2014 and are collapsed to the state by year level (weighted). All regressions include controls for state and year fixed effects. The results are weighted by the sum of the CPS weights in the cell. Standard errors are clustered by state and shown in parentheses. 
Table 4: Effects of Unemployment Rate on Private Income and After-Tax-and-Transfer Child Poverty - Heterogeneity Across Demographic Subgroups

\begin{tabular}{|c|c|c|c|c|c|c|c|c|c|}
\hline & \multicolumn{5}{|c|}{ Child ATT $100 \%$ Poverty } & \multicolumn{4}{|c|}{ Child $100 \%$ Poverty } \\
\hline & Married & Single & White & Black & Hispanic & $\begin{array}{l}\text { Immigrant } \\
\text { PI Poverty }\end{array}$ & $\begin{array}{c}\text { Immigrant } \\
\text { ATT } \\
\text { Poverty }\end{array}$ & $\begin{array}{l}\text { Native } \\
\text { PI } \\
\text { Poverty }\end{array}$ & $\begin{array}{l}\text { Native } \\
\text { ATT } \\
\text { Poverty }\end{array}$ \\
\hline UR & $\begin{array}{c}0.490 \\
(0.099)\end{array}$ & $\begin{array}{c}0.645 \\
(0.191)\end{array}$ & $\begin{array}{c}0.363 \\
(0.092)\end{array}$ & $\begin{array}{c}0.492 \\
(0.357)\end{array}$ & $\begin{array}{c}1.119 \\
(0.218)\end{array}$ & $\begin{array}{c}1.197 \\
(0.467)\end{array}$ & $\begin{array}{c}1.171 \\
(0.250)\end{array}$ & $\begin{array}{c}0.724 \\
(0.119)\end{array}$ & $\begin{array}{c}0.358 \\
(0.109)\end{array}$ \\
\hline$\%$ Impact & 8.5 & 2.6 & 5.6 & 2.2 & 6.1 & 4.5 & 8.3 & 3.7 & 3.4 \\
\hline Mean y & 0.057 & 0.250 & 0.065 & 0.226 & 0.183 & 0.265 & 0.141 & 0.197 & 0.107 \\
\hline Mean UR & 0.064 & 0.065 & 0.063 & 0.064 & 0.067 & 0.067 & 0.067 & 0.063 & 0.063 \\
\hline $\mathrm{N}$ & 5791 & 5024 & 2827 & 2459 & 2854 & 4956 & 4956 & 5859 & 5859 \\
\hline $\begin{array}{l}\text { Notes: Tat } \\
\text { and the st } \\
\text { Data are } \\
\text { demograph } \\
\text { Demograp } \\
\text { immigratic } \\
\text { CPS weigh }\end{array}$ & $\begin{array}{l}\text { hows tl } \\
\text { nemplc } \\
\text { the C } \\
\text { group 1 } \\
\text { roups } \\
\text { hether } \\
\text { the ce }\end{array}$ & $\begin{array}{l}\text { elations } \\
\text { ent rate } \\
\text { ASEC } \\
1 \text { (weig } \\
\text { determi } \\
\text { head c } \\
\text { tandard }\end{array}$ & $\begin{array}{l}\text { betw } \\
\text { ross c } \\
\text { lendar } \\
\text { d). A } \\
\text { dacco } \\
\text { heir s } \\
\text { rors ar }\end{array}$ & $\begin{array}{l}\text { child p } \\
\text { graphic } \\
\text { s } 200 \\
\text { gressio } \\
\text { to the } \\
\text { are in } \\
\text { stered }\end{array}$ & $\begin{array}{l}\text { ate inco } \\
\text { roups. } \\
\text { o } 2014 \\
\text { include } \\
\text { mograp } \\
\text { igrants. } \\
\text { state an }\end{array}$ & $\begin{array}{l}\text { poverty o } \\
\text { poverty th } \\
\mathrm{d} \text { are coll } \\
\text { ontrols for } \\
\text { s of the ho } \\
\text { e results a } \\
\text { hown in pa }\end{array}$ & $\begin{array}{l}\text { or after-t } \\
\text { hreshold } \\
\text { lapsed to } \\
\text { r state a } \\
\text { ousehold } \\
\text { are weig } \\
\text { renthese }\end{array}$ & $\begin{array}{l}\text { Ind-trar } \\
\text { he His } \\
\text { e state } \\
\text { year } f \\
\text { d, or i }\end{array}$ & $\begin{array}{l}\text { poverty } \\
\text { cal SPM } \\
\text { year by } \\
\text { effects } \\
\text { e case of }\end{array}$ \\
\hline
\end{tabular}


Table 5: Effects of Unemployment Rate on Private Income and After-Tax-and-Transfer Child $100 \%$ Poverty - Sensitivity to the Poverty Threshold

\begin{tabular}{|c|c|c|c|c|c|c|c|c|}
\hline & \multicolumn{2}{|c|}{ SPM Historical } & \multicolumn{2}{|c|}{ SPM Anchored } & \multicolumn{2}{|c|}{ Official Poverty } & \multicolumn{2}{|c|}{ OECD Measure } \\
\hline & PI & ATT & PI & ATT & PI & ATT & PI & ATT \\
\hline UR & $\begin{array}{c}0.871 \\
(0.134)\end{array}$ & $\begin{array}{c}0.538 \\
(0.096)\end{array}$ & $\begin{array}{c}0.892 \\
(0.124)\end{array}$ & $\begin{array}{c}0.461 \\
(0.109)\end{array}$ & $\begin{array}{c}0.859 \\
(0.137)\end{array}$ & $\begin{array}{c}0.478 \\
(0.114)\end{array}$ & $\begin{array}{c}1.075 \\
(0.193)\end{array}$ & $\begin{array}{r}0.975 \\
(0.150)\end{array}$ \\
\hline \% Impact & 4.1 & 4.7 & 4.2 & 3.9 & 4.3 & 4.5 & 3.1 & 3.4 \\
\hline Mean y & 0.212 & 0.114 & 0.212 & 0.117 & 0.201 & 0.105 & 0.348 & 0.290 \\
\hline Mean UR & 0.064 & 0.064 & 0.064 & 0.064 & 0.064 & 0.064 & 0.064 & 0.064 \\
\hline $\mathrm{N}$ & 765 & 765 & 765 & 765 & 765 & 765 & 765 & 765 \\
\hline
\end{tabular}

Notes: Table shows the relationship between the unemployment rate and children having household private income after-tax-and-transfer income below the Historical SPM threshold (columns 1 and 2), the anchored SPM threshold (columns 3 and 4), the official poverty threshold (columns 5 and 6 ) and the OECD poverty threshold (columns 7 and 8). Data are from the CPS ASEC calendar years 2000-2014 and are collapsed to the state by year level (weighted). All regressions include controls for state and year fixed effects. The results are weighted by the sum of the CPS weights in the cell. Standard errors are clustered by state and shown in parentheses. 
Table 6: Effects of Unemployment Rate on Private Income and After-Tax-and-Transfer Child Poverty - Sensitivity to the Treatment of Medical Expenses and Benefits

\begin{tabular}{lcccccc}
\hline & \multicolumn{3}{c}{ SPM Historical } & \multicolumn{3}{c}{ SPM Anchored } \\
\cline { 3 - 6 } & ATT & $\begin{array}{c}\text { ATT }+ \\
\text { Medical }\end{array}$ & $\begin{array}{c}\text { ATT minus } \\
\text { MOOP }\end{array}$ & ATT & $\begin{array}{c}\text { ATT }+ \\
\text { Medical }\end{array}$ & $\begin{array}{c}\text { minus } \\
\text { MOOP }\end{array}$ \\
\hline UR & & & & & & \\
& 0.512 & 0.490 & 0.662 & 0.441 & 0.500 & 0.517 \\
\% Impact & $(0.095)$ & $(0.094)$ & $(0.102)$ & $(0.105)$ & $(0.107)$ & $(0.111)$ \\
Mean y & 4.5 & 4.6 & 4.7 & 3.8 & 4.7 & 3.6 \\
Mean UR & 0.114 & 0.106 & 0.142 & 0.117 & 0.106 & 0.145 \\
& 0.064 & 0.064 & 0.064 & 0.064 & 0.064 & 0.064 \\
$\mathrm{~N}$ & & & & & & \\
\hline \hline
\end{tabular}

Notes: Table shows the relationship between the unemployment rate and children having household private income or after-tax-and-transfer income below the Historical SPM thresholds (columns 1-3) and anchored SPM thresholds (columns 4-6). Data are from the CPS ASEC calendar years 2000-2013 and are collapsed to the state by year level (weighted). Column 1 and 4 specifications are for the determinants of poverty using our baseline ATT measure of resources, column 2 and 5 specifications are for the determinants of poverty using a resource measure that adds the fungible value of Medicaid/CHIP and Medicare and the employer contribution to HI premiums to ATT resources, and column 3 and 6 specifications are for the determinants of poverty after subtracting MOOP, child care expenses, and other work expenses from ATT resources. All regressions include controls for state and year fixed effects. The results are weighted by the sum of the CPS weights in the cell. Standard errors are clustered by state and shown in parentheses. 
Table A.1: Resource Measures used in Alternative Poverty Measures

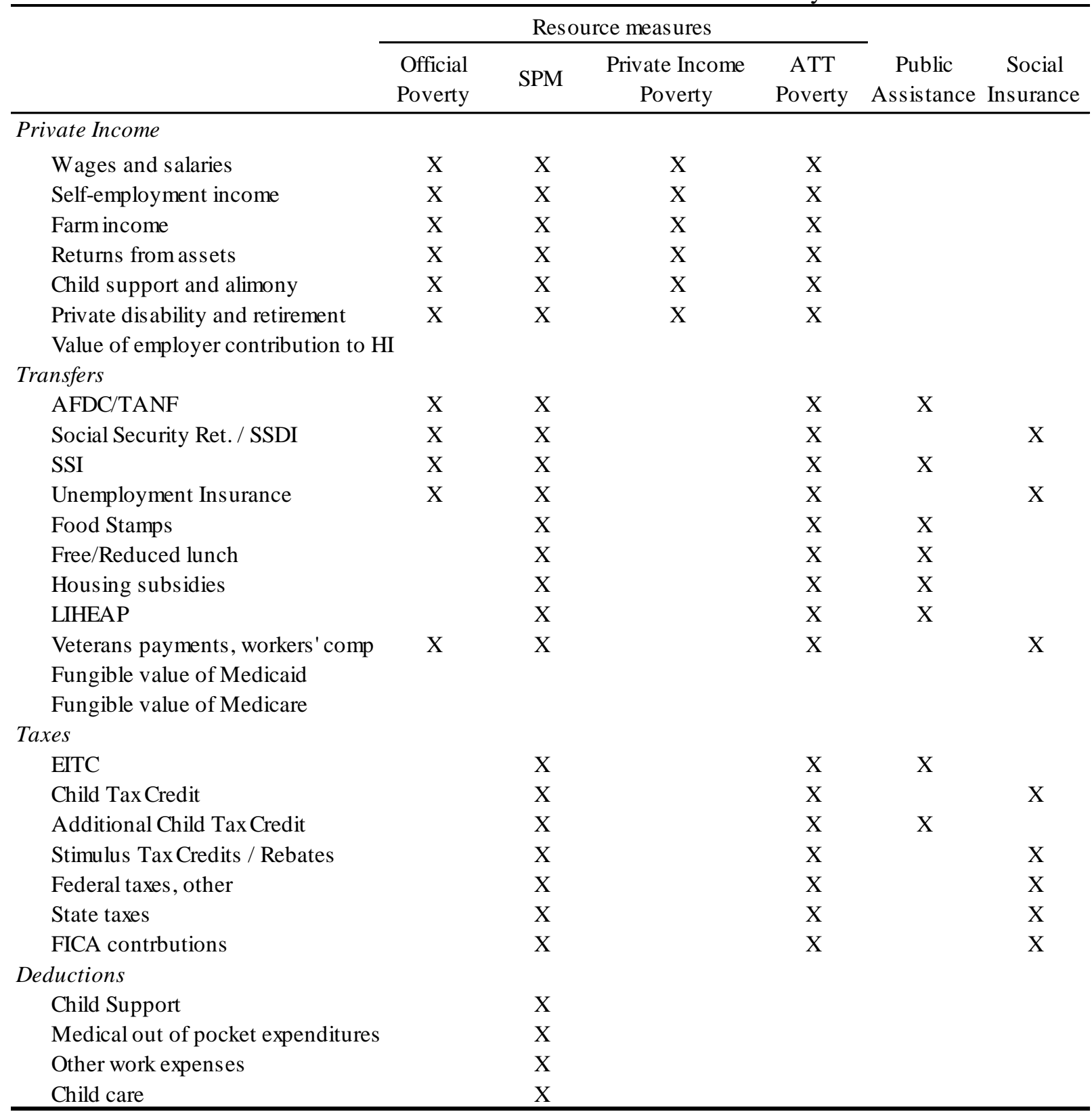


Table A.2: Effects of Unemployment Rate on Private Income and After-Tax-and-Transfer Child 100\% Poverty - Heterogeneity Across Demographic Subgroups

\begin{tabular}{|c|c|c|c|c|c|c|c|c|c|c|c|c|}
\hline & \multicolumn{2}{|c|}{ All } & \multicolumn{2}{|c|}{ Married } & \multicolumn{2}{|c|}{ Single } & \multicolumn{2}{|c|}{ White } & \multicolumn{2}{|c|}{ Black } & \multicolumn{2}{|c|}{ Hispanic } \\
\hline & PI & ATT & PI & ATT & PI & ATT & PI & ATT & PI & ATT & PI & ATT \\
\hline UR & $\begin{array}{c}0.891 \\
(0.105)\end{array}$ & $\begin{array}{c}0.550 \\
(0.099)\end{array}$ & $\begin{array}{c}0.791 \\
(0.125)\end{array}$ & $\begin{array}{c}0.490 \\
(0.099)\end{array}$ & $\begin{array}{c}1.074 \\
(0.313)\end{array}$ & $\begin{array}{c}0.645 \\
(0.191)\end{array}$ & $\begin{array}{c}0.655 \\
(0.136)\end{array}$ & $\begin{array}{c}0.363 \\
(0.092)\end{array}$ & $\begin{array}{c}0.887 \\
(0.361)\end{array}$ & $\begin{array}{c}0.492 \\
(0.357)\end{array}$ & $\begin{array}{c}1.432 \\
(0.329)\end{array}$ & $\begin{array}{c}1.119 \\
(0.218)\end{array}$ \\
\hline$\%$ Impact & 4.2 & 4.8 & 6.4 & 8 . & 2.6 & 2 . & 5.1 & 5.6 & 2.3 & 2.2 & 4.2 & 6.1 \\
\hline Mean y & 0.212 & 0.114 & 0.124 & 0.057 & 0.421 & 0.250 & 0.128 & 0.065 & 0.387 & 0.226 & 0.337 & 0.183 \\
\hline Mean UR & 0.064 & 0.064 & 0.064 & 0.064 & 0.065 & 0.065 & 0.063 & 0.063 & 0.064 & 0.064 & 0.067 & 0.067 \\
\hline $\mathrm{N}$ & 10815 & 10815 & 5791 & 5791 & 5024 & 5024 & 2827 & 2827 & 2459 & 2459 & 2854 & 2854 \\
\hline
\end{tabular}

Notes: Table shows the relationship between child private income poverty or after-tax-and-transfer poverty and the state unemployment rate across demographic groups. The poverty threshold is the Historical SPM. Data are from the CPS ASEC calendar years 2000-2014 and are collapsed to the state by year by demographic group level (weighted). All regressions include controls for state and year fixed effects. Demographic groups are determined according to the demographics of the household head, or in the case of immigration, whether the head or their spouse are immigrants. The results are weighted by the sum of the CPS weights in the cell. Standard errors are clustered by state and shown in parentheses. 
Table A.3: Effects of Unemployment Rate on Private Income and After-Tax-and-Transfer Child Poverty - Sensitivity to the Poverty Threshold

\begin{tabular}{|c|c|c|c|c|c|c|c|c|}
\hline & \multicolumn{2}{|c|}{ SPM Historical } & \multicolumn{2}{|c|}{ SPM Anchored } & \multicolumn{2}{|c|}{ Official Poverty } & \multicolumn{2}{|c|}{ OECD Measure } \\
\hline & PI & ATT & PI & ATT & PI & ATT & PI & ATT \\
\hline & \multicolumn{8}{|c|}{ A. $50 \%$ Poverty } \\
\hline \multirow[t]{2}{*}{ UR } & 0.509 & 0.198 & 0.553 & 0.183 & 0.457 & 0.162 & 0.807 & 0.308 \\
\hline & $(0.097)$ & $(0.057)$ & $(0.088)$ & $(0.060)$ & $(0.095)$ & $(0.055)$ & $(0.121)$ & $(0.095)$ \\
\hline$\%$ Impact & 4.8 & 6.3 & 5.0 & 5.6 & 4.4 & 5.5 & 4.9 & 4.2 \\
\hline \multirow[t]{2}{*}{ Mean y } & 0.107 & 0.031 & 0.108 & 0.033 & 0.103 & 0.029 & 0.166 & 0.073 \\
\hline & \multicolumn{8}{|c|}{ B. $100 \%$ Poverty } \\
\hline \multirow[t]{2}{*}{ UR } & 0.871 & 0.538 & 0.892 & 0.461 & 0.859 & 0.478 & 1.075 & 0.975 \\
\hline & $(0.134)$ & $(0.096)$ & $(0.124)$ & $(0.109)$ & $(0.137)$ & $(0.114)$ & $(0.193)$ & $(0.150)$ \\
\hline$\%$ Impact & 4.1 & 4.7 & 4.2 & 3.9 & 4.3 & 4.5 & 3.1 & 3.4 \\
\hline \multirow[t]{2}{*}{ Mean y } & 0.212 & 0.114 & 0.212 & 0.117 & 0.201 & 0.105 & 0.348 & 0.290 \\
\hline & \multicolumn{8}{|c|}{ C. $150^{\prime} \%$ Poverty } \\
\hline \multirow{2}{*}{ UR } & 0.988 & 0.928 & 0.958 & 0.944 & 0.982 & 0.895 & 0.972 & 0.944 \\
\hline & $(0.152)$ & $(0.157)$ & $(0.172)$ & $(0.127)$ & $(0.171)$ & $(0.141)$ & $(0.171)$ & $(0.167)$ \\
\hline$\%$ Impact & 3.0 & 3.6 & 2.9 & 3.7 & 3.2 & 3.9 & 1.9 & 1.8 \\
\hline \multirow[t]{2}{*}{ Mean y } & 0.326 & 0.255 & 0.326 & 0.257 & 0.308 & 0.231 & 0.512 & 0.526 \\
\hline & \multicolumn{8}{|c|}{ D. $200 \%$ Poverty } \\
\hline \multirow[t]{2}{*}{ UR } & 0.978 & 0.959 & 0.812 & 1.001 & 1.014 & 1.001 & 0.734 & 0.580 \\
\hline & $(0.165)$ & $(0.151)$ & $(0.231)$ & $(0.166)$ & (0.174) & $(0.162)$ & $(0.182)$ & $(0.174)$ \\
\hline$\%$ Impact & 2.3 & 2.3 & 1.9 & 2.4 & 2.5 & 2.6 & 1.1 & 0.8 \\
\hline Mean y & 0.432 & 0.417 & 0.431 & 0.412 & 0.409 & 0.382 & 0.645 & 0.693 \\
\hline $\mathrm{N}$ & 765 & 765 & 765 & 765 & 765 & 765 & 765 & 765 \\
\hline
\end{tabular}

Notes: Table shows the relationship between the unemployment rate and having household private income or after-tax-and-transfer income below various multiples of the Historical SPM threshold (columns 1 and 2), the anchored SPM threshold (columns 3 and 4), the official poverty threshold (columns 5 and 6) and the OECD poverty threshold (columns 7 and 8). Data are from the CPS ASEC calendar years 2000-2014 and are collapsed to the state by year level (weighted). All regressions include controls for state and year fixed effects. The results are weighted by the sum of the CPS weights in the cell. Standard errors are clustered by state and shown in parentheses. 
Table A.4: Effects of Unemployment Rate on Private Income and After-Tax-and-Transfer Child Poverty - Sensitivity to the Treatment of Medical Expenses and Benefits

\begin{tabular}{|c|c|c|c|c|c|c|}
\hline & \multicolumn{3}{|c|}{$\underline{\text { SPM Historical }}$} & \multicolumn{3}{|c|}{$\underline{\text { SPM Anchored }}$} \\
\hline & ATT & $\begin{array}{l}\text { ATT + } \\
\text { Medical }\end{array}$ & $\begin{array}{l}\text { ATT minus } \\
\text { MOOP }\end{array}$ & ATT & $\begin{array}{l}\text { ATT + } \\
\text { Medical }\end{array}$ & $\begin{array}{c}\text { ATT minus } \\
\text { MOOP }\end{array}$ \\
\hline & \multicolumn{6}{|c|}{ A. $50 \%$ Poverty } \\
\hline UR & $\begin{array}{c}0.187 \\
(0.054)\end{array}$ & $\begin{array}{c}0.182 \\
(0.051)\end{array}$ & $\begin{array}{c}0.186 \\
(0.074)\end{array}$ & $\begin{array}{c}0.177 \\
(0.058)\end{array}$ & $\begin{array}{c}0.179 \\
(0.055)\end{array}$ & $\begin{array}{c}0.181 \\
(0.064)\end{array}$ \\
\hline$\%$ Impact & 6.0 & 6.0 & 4.7 & 5.4 & 5.6 & 4.5 \\
\hline Mean y & 0.031 & 0.031 & 0.039 & 0.033 & 0.032 & 0.040 \\
\hline UR & $\begin{array}{c}0.512 \\
(0.095)\end{array}$ & $\begin{array}{c}0.490 \\
(0.094)\end{array}$ & $\begin{array}{c}\text { B. 100\% } \\
0.662 \\
(0.102)\end{array}$ & $\begin{array}{c}\text { Poverty } \\
0.441 \\
(0.105)\end{array}$ & $\begin{array}{c}0.500 \\
(0.107)\end{array}$ & $\begin{array}{c}0.517 \\
(0.111)\end{array}$ \\
\hline$\%$ Impact & 4.5 & 4.6 & 4.7 & 3.8 & 4.7 & 3.6 \\
\hline Mean y & 0.114 & 0.106 & 0.142 & 0.117 & 0.106 & 0.145 \\
\hline UR & $\begin{array}{c}0.929 \\
(0.161)\end{array}$ & $\begin{array}{c}0.938 \\
(0.111)\end{array}$ & $\begin{array}{c}\text { C. } 150 \% \\
0.940 \\
(0.167)\end{array}$ & $\begin{array}{c}\text { Poverty } \\
0.939 \\
(0.124)\end{array}$ & $\begin{array}{c}0.906 \\
(0.109)\end{array}$ & $\begin{array}{c}0.993 \\
(0.120)\end{array}$ \\
\hline$\%$ Impact & 3.6 & 4.6 & 3.0 & 3.7 & 4.3 & 3.2 \\
\hline Mean y & 0.255 & 0.204 & 0.315 & 0.256 & 0.209 & 0.313 \\
\hline UR & $\begin{array}{c}0.948 \\
(0.153)\end{array}$ & $\begin{array}{c}1.061 \\
(0.115)\end{array}$ & $\begin{array}{c}\text { D. 200\% } \\
0.860 \\
(0.165)\end{array}$ & $\begin{array}{c}\text { Poverty } \\
1.005 \\
(0.169)\end{array}$ & $\begin{array}{c}1.078 \\
(0.116)\end{array}$ & $\begin{array}{c}0.871 \\
(0.180)\end{array}$ \\
\hline$\%$ Impact & 2.3 & 3.1 & 1.8 & 2.4 & 3.2 & 1.8 \\
\hline Mean y & 0.416 & 0.341 & 0.477 & 0.411 & 0.339 & 0.472 \\
\hline $\mathrm{N}$ & 714 & 714 & 714 & 714 & 714 & 714 \\
\hline
\end{tabular}

Notes: Table shows the relationship between the unemployment rate and children having household private income or after tax and transfer income below various multiples of the Historical SPM thresholds (columns 1-3) and anchored SPM thresholds (columns 4-6). Data are from the CPS ASEC calendar years 2000-2013 and are collapsed to the state by year level (weighted). Column 1 and 4 specifications are for the determinants of poverty using our baseline ATT measure of resources, column 2 and 4 specifications are for the determinants of poverty using a resource measure that adds the fungible value of Medicaid/CHIP and Medicare and the employer contribution to health insurance to ATT resources, and column 3 and 6 specifications are for the determinants of poverty after subtracting MOOP, child care expenses, and other work expenses from ATT resources. All regressions include controls for state and year fixed effects. The results are weighted by the sum of the CPS weights in the cell. Standard errors are clustered by state and shown in parentheses. 
Table A.5: Effects of Unemployment Rate on Private Income and After-Tax-and-Transfer Child Poverty - Sensitivity to Model Specification

\begin{tabular}{|c|c|c|c|c|c|c|c|c|}
\hline & \multicolumn{4}{|c|}{ Private Income Poverty } & \multicolumn{4}{|c|}{$\underline{\text { ATT Poverty }}$} \\
\hline & $<50 \%$ & $<100 \%$ & $<150 \%$ & $<200 \%$ & $<50 \%$ & $<100 \%$ & $<150 \%$ & $<200 \%$ \\
\hline \multirow{4}{*}{ UR } & \multicolumn{8}{|c|}{ A. Main specification } \\
\hline & 0.509 & 0.871 & 0.988 & 0.978 & 0.198 & 0.538 & 0.928 & 0.959 \\
\hline & $(0.097)$ & $(0.134)$ & $(0.152)$ & $(0.165)$ & $(0.057)$ & $(0.096)$ & $(0.157)$ & $(0.151)$ \\
\hline & \multicolumn{8}{|c|}{ B. Adding individual demographic controls (micro regression) } \\
\hline \multirow[t]{2}{*}{ UR } & 0.592 & 1.004 & 1.146 & 1.142 & 0.219 & 0.621 & 1.068 & 1.121 \\
\hline & $(0.085)$ & $(0.124)$ & $(0.161)$ & $(0.192)$ & $(0.055)$ & $(0.095)$ & $(0.171)$ & $(0.183)$ \\
\hline $\mathrm{N}$ & 874866 & 874866 & 874866 & 874866 & 874866 & 874866 & 874866 & 874866 \\
\hline \multirow{3}{*}{ UR } & \multicolumn{8}{|c|}{ C. Add state time varying policies } \\
\hline & 0.475 & 0.865 & 0.979 & 0.975 & 0.193 & 0.509 & 0.901 & 0.938 \\
\hline & $(0.104)$ & $(0.129)$ & $(0.142)$ & $(0.143)$ & $(0.061)$ & $(0.103)$ & $(0.149)$ & $(0.141)$ \\
\hline & \multicolumn{8}{|c|}{ D. Add state linear trends } \\
\hline UR & 0.372 & 0.822 & 0.974 & 1.029 & 0.105 & 0.372 & 0.726 & 0.881 \\
\hline & $(0.139)$ & $(0.156)$ & $(0.153)$ & $(0.157)$ & $(0.077)$ & $(0.141)$ & $(0.142)$ & $(0.139)$ \\
\hline
\end{tabular}

Notes: Table shows the relationship between the unemployment rate and children having household private income or after-tax-and-transfer income below various multiples of the Historical SPM threshold. Data are from the CPS ASEC calendar years 2000-2014 and are collapsed to the state by year level (weighted) for Panels A, C, and D. All regressions include controls for state and year fixed effects. Panel A repeats our main specifications. panel B uses individual controls and individual data, including age dummies for the household head's age in years; dummies for the head being of Hispanic ethnicity, a non-Hispanic white, a non-Hispanic black, or non-Hispanic other race (excludes Asian heads); dummies for household head education being a high school graduate, having some college, or being a college graduate; dummies or the number of persons in the household; a dummy for the head being male; and a dummy the head being married. panel $\mathrm{C}$ adds state-level time varying controls for the Medicaid eligibility threshold for pregnant women and young children, state-level EITCs, the binding minimum wage, the average UI replacement rate (Kuka, 2016), and the TANF guarantee. The results are weighted by the sum of the CPS weights in the cell. Standard errors are clustered by state and shown in parentheses. 
Table A.6: Effects of Cycles on Private Income and After-Tax-and-Transfer Child Poverty Sensitivity to the Measure of Cycles

\begin{tabular}{|c|c|c|c|c|c|c|c|c|}
\hline & \multicolumn{4}{|c|}{$\underline{\text { Private Income Poverty }}$} & \multicolumn{4}{|c|}{$\underline{\text { ATT Income Poverty }}$} \\
\hline & $<50 \%$ & $<100 \%$ & $<150 \%$ & $<200 \%$ & $<50 \%$ & $<100 \%$ & $<150 \%$ & $<200 \%$ \\
\hline & \multicolumn{8}{|c|}{ A. Main specification (unemployment rate) } \\
\hline \multirow[t]{2}{*}{ UR } & 0.509 & 0.871 & 0.988 & 0.978 & 0.198 & 0.538 & 0.928 & 0.959 \\
\hline & $(0.097)$ & $(0.134)$ & $(0.152)$ & $(0.165)$ & $(0.057)$ & $(0.096)$ & $(0.157)$ & $(0.151)$ \\
\hline \multirow[t]{2}{*}{$\%$ Impact } & 4.8 & 4.1 & 3.0 & 2.3 & 6.3 & 4.7 & 3.6 & 2.3 \\
\hline & \multicolumn{8}{|c|}{ B. Labor market measure $=$ employment-to-population ratio } \\
\hline \multirow[t]{3}{*}{ EPOP } & -0.565 & -0.728 & -0.890 & -0.814 & -0.155 & -0.530 & -0.750 & -0.837 \\
\hline & $(0.080)$ & $(0.099)$ & $(0.130)$ & $(0.140)$ & $(0.049)$ & $(0.091)$ & $(0.111)$ & $(0.134)$ \\
\hline & \multicolumn{8}{|c|}{ C. Labor market measure $=$ state GDP per capita } \\
\hline GDP PC & 0.006 & -0.021 & -0.262 & -0.391 & -0.058 & -0.074 & -0.151 & -0.143 \\
\hline & $(0.273)$ & $(0.436)$ & $(0.637)$ & $(0.777)$ & $(0.157)$ & $(0.332)$ & $(0.533)$ & $(0.731)$ \\
\hline \multicolumn{9}{|c|}{$\begin{array}{l}\text { Notes: Table shows the relationship between economic cycles and children having household } \\
\text { private income or after-tax-and-transfer income below various multiples of the Historical SPM } \\
\text { threshold. Data are from the CPS ASEC calendar years } 2000 \text { through } 2014 \text { and are collapsed to } \\
\text { the state by year level (weighted). All regressions include controls for state and year fixed effects. } \\
\text { Panel A repeats our main specification, panel B uses the EPOP as the labor market measure, and } \\
\text { panel C uses chained real state GDP per capita. The results are weighted by the sum of the CPS } \\
\text { weights in the cell. Standard errors are clustered by state and shown in parentheses. Notably, none } \\
\text { of the panel C regressions are statistically significant at the } 5 \text { percent level. }\end{array}$} \\
\hline
\end{tabular}


Table A.7: Effects of Unemployment Rate on Private Income and After-Tax-and-Transfer Child Poverty - Sensitivity to Adding Lags of the Unemployment Rate

\begin{tabular}{|c|c|c|c|c|c|c|c|c|}
\hline & \multicolumn{4}{|c|}{$\underline{\text { Private Income Poverty }}$} & \multicolumn{4}{|c|}{ ATT Poverty } \\
\hline & $<50 \%$ & $<100 \%$ & $<150 \%$ & $<200 \%$ & $<50 \%$ & $<100 \%$ & $<150 \%$ & $<200 \%$ \\
\hline & \multicolumn{8}{|c|}{ A. Main specification } \\
\hline \multirow[t]{3}{*}{ UR } & 0.509 & 0.871 & 0.988 & 0.978 & 0.198 & 0.538 & 0.928 & 0.959 \\
\hline & $(0.097)$ & $(0.134)$ & $(0.152)$ & $(0.165)$ & $(0.057)$ & $(0.096)$ & $(0.157)$ & $(0.151)$ \\
\hline & \multicolumn{8}{|c|}{ B. Adding one year lag } \\
\hline \multirow[t]{2}{*}{$\mathrm{UR}(\mathrm{t})$} & 0.343 & 0.575 & 0.782 & 0.674 & 0.258 & 0.322 & 0.599 & 0.563 \\
\hline & $(0.187)$ & $(0.198)$ & $(0.234)$ & $(0.203)$ & $(0.071)$ & $(0.189)$ & $(0.222)$ & $(0.215)$ \\
\hline \multirow[t]{3}{*}{$\mathrm{UR}(\mathrm{t}-1)$} & 0.205 & 0.366 & 0.255 & 0.376 & -0.075 & 0.267 & 0.407 & 0.490 \\
\hline & $(0.166)$ & $(0.187)$ & $(0.260)$ & $(0.251)$ & $(0.079)$ & $(0.176)$ & $(0.214)$ & $(0.270)$ \\
\hline & \multicolumn{8}{|c|}{ C. Adding one and two year lags } \\
\hline \multirow[t]{2}{*}{$\mathrm{UR}(\mathrm{t})$} & 0.468 & 0.604 & 0.829 & 0.811 & 0.289 & 0.427 & 0.742 & 0.688 \\
\hline & $(0.210)$ & $(0.200)$ & $(0.231)$ & $(0.214)$ & $(0.078)$ & $(0.214)$ & $(0.234)$ & $(0.231)$ \\
\hline \multirow[t]{2}{*}{$\mathrm{UR}(\mathrm{t}-1)$} & -0.206 & 0.268 & 0.101 & -0.077 & -0.176 & -0.081 & -0.066 & 0.076 \\
\hline & $(0.276)$ & $(0.256)$ & $(0.310)$ & $(0.326)$ & $(0.125)$ & $(0.270)$ & $(0.300)$ & $(0.333)$ \\
\hline \multirow[t]{2}{*}{$\mathrm{UR}(\mathrm{t}-2)$} & 0.387 & 0.093 & 0.146 & 0.426 & 0.095 & 0.327 & 0.444 & 0.390 \\
\hline & $(0.181)$ & $(0.210)$ & $(0.260)$ & $(0.237)$ & $(0.110)$ & $(0.169)$ & $(0.224)$ & $(0.224)$ \\
\hline
\end{tabular}

Notes: Table shows the relationship between the unemployment rate and children having household private income or after-tax-and-transfer income below various multiples of the Historical SPM threshold. Data are from the CPS ASEC calendar years 2000 through 2014 and are collapsed to the state by year level (weighted). All regressions include controls for state and year fixed effects. Panel A repeats the baseline specifications. Panel B specifications add a one-year lag of the unemployment rate, and panel $\mathrm{C}$ specifications add the one- and two-year lags of the unemployment rate. The results are weighted by the sum of the CPS weights in the cell. Standard errors are clustered by state and shown in parentheses. A number of the estimated coefficients on the lags of the poverty rate are insignificant at the 5 percent level. 